\title{
A Process-Based Guide for International Entrepreneurs while investing in the Agri-food Sector of an Emerging Economy: A Multi-Layer Decision-Making Approach
}

\author{
Hannan Amoozad Mahdiraji ${ }^{1,2}$ \\ ${ }^{1}$ Leicester Castle Business School \\ De Montfort University, Leicester, UK \\ Hannan.amoozadmahdiraji@dmu.ac.uk
}

${ }^{2}$ Faculty of Management

University of Tehran, Tehran, Iran

h.amoozad@ut.ac.ir

Moein Beheshti

Faculty of Management

University of Tehran, Tehran, Iran

mbeheshti@ut.ac.ir

Seyed Hossein Razavi Hajiagha

Faculty of Management and Finance,

Khatam University, Tehran, Iran

h.razavi@khatam.ac.ir

Niloofar Ahmadzadeh Kandi

Sydney Business School

University of Wollongong, Wollongong, Australia

Nak127@uowmail.edu.au

Hasan Boudlaie

University of Tehran, Kish International Campus,

Kish Island, Iran,

hasanboudlaie@ut.ac.ir 


\title{
A Process-Based Guide for International Entrepreneurs while investing in the Agri-food Sector of an Emerging Economy: A Multi-Layer Decision-Making Approach
}

\begin{abstract}
Purpose. Due to the political, economic, and infrastructure barriers and risks that international entrepreneurs (IEs) face when researching an emerging economy's agri-food sector, this research aims to identify the major barriers, analyze their relationships, quantify their importance, classify, and rank them. Thus, the IEs will gain a better understanding and vision of their decision-making processes in this era.

Design. To do this, the authors first created a list of barriers to entry for IEs into Iran's rising economy's agri-food industry. Following that, a multi-layer decision-making approach was developed and implemented to accomplish the research objectives. The first stage utilized a hybrid of interpretive structural modelling (ISM) and cross-impact matrix multiplication applied to classification (MICMAC) to depict the level-based conceptual model and classification of the IEs obstacles to entry into the agri-food sector. Following that, a hybrid Decision-Making Trial and Evaluation Laboratory (DEMATEL) and hierarchical analytic process (ANP) called DANP were utilized to present a causal relationship between the barriers, identify their causes and effects, and quantify the relevance of each barrier.
\end{abstract}

Findings. After employing the multi-layer decision-making approach, the results demonstrated that fundamental limitations, including infrastructure and technology limitations, are the most critical barriers alongside policy factors encompassing governmental support and access to global or regional economy/market. According to the results, innovation and economic sustainability of the agri-food supply chain also matter. All of these critical barriers are intertwined and should be planned and solved simultaneously. Furthermore, based on DANP results, the sustainability pillars (economy, environment, society), besides the low efficiency of the agri-food sector in Iran, should be investigated further for future policy makings.

Originality. Using a hybrid multi-layer decision-making approach for analyzing the barriers of investment in the agri-food sector of the emerging economy of Iran for the international entrepreneurs. Moreover, providing implications and insights for IEs and officials for decision-making in the future.

Keywords. Multi-Layer Decision Making, International Entrepreneurs investments, Agrifood Sector, Emerging Economy, DANP, ISM-MICMAC. 


\section{Introduction}

Global agricultural markets continue to become more complex as consumer behaviour evolves. Due to the development of food safety, quality standards, and technological advancements, these changes have altered the structure of the agrifood industry and its value chain (Liu et al., 2019). The increased level of differentiation and added value has affected the product's farm and retail value. As a result, the vicissitudes of market behaviour affect the profitability of entrepreneurs seeking to capitalise on food industry opportunities and establish their businesses (van der Vorst et al., 2011). Although several recent studies, such as the Global Entrepreneurship Monitor (GEM, 2020) and the Organization for Economic Cooperation and Development (OECD, 2019), have downplayed the entrepreneurial potential of emerging economy countries, these countries have proven to be pristine markets with high investment potential in recent years (Cheraghi et al., 2020). Apart from the emphasis on projecting investment opportunities in agriculture, entrepreneurs must overcome several fundamental obstacles in less developed countries. Agriculture and food are critical components of all economies worldwide. Thus, in recent years, the primary impediments to expanding this industry have been socio-environmental concerns such as agrifood waste and sustainability (Morone et al., 2019), food security (Mayett-Moreno and López Oglesby, 2018), and food supply and sufficiency (Mayett-Moreno and López Oglesby, 2018). Numerous agricultural economists believe that agricultural products' markets and distribution systems in developing countries are complex and inefficient (Devaux et al., 2018). As a result of the oversupply and occasionally undersupply of goods in such nations' markets, sharp price fluctuations occur, creating dissatisfaction on both sides, the consumer and the producer (Gold et al., 2017).

Additionally, scientists demonstrate that a fixed mindset among entrepreneurs and formers is a pernicious factor impeding the adoption of a productive business model in the agrifood industry, according to a collaborative innovation theory (Chesbrough, 2011). A project extrapolates two learning and innovation mindsets that contribute to farmers' growth, improved understanding, and cooperation in the industry (Ulvenblad et al., 2020). Numerous other studies have emphasised the critical role of risk management (Shkolnyi and Novak, 2020) or unexpected environmental morphs such as COIVD-19 (Apostolopoulos et al., 2021) as a significant impediment to agrifood investment. When combined with supply chain effectiveness and responsiveness (Folinas et al., 2013), these issues have shifted the emphasis to the value chain. Establishing a foundation for entrepreneurial activities enhances agricultural marketing and trade, increases agricultural product productivity and sustainability (Bartolucci et al., 2020), and achieves lean production (Cuer et al., 2019). Thus, inchoate factor mining and a disregard for the connections between opportunities and threats in this industry are the most significant gaps in the literature review. The literature review discusses entrepreneurial opportunities and barriers from a variety of perspectives. However, investment in Iran has not been weighed against the threat of various challenges such as governmental regulations or port management for supplements. Nonetheless, the authors believe that a thorough examination of both the advantages and disadvantages of investment provides a clear understandi8ng of its feasibility. 
The following article responds to academic articles such as (Tsolakis et al., 2019) that discuss the benefits and drawbacks of developing a comprehensive entrepreneurship framework in the agrifood industry. Although recent works have discussed various aspects of entrepreneurial opportunities and challenges, particularly in more developing countries such as Iran or India, the following paper takes a more holistic approach to weighing the advantages and disadvantages of investments in the agrifood industry in such countries. Numerous researchers, such as (Ay, 2019), believe that investment in Iran will continue to be discouraged even after the sanctions are lifted and that neighbouring European countries, such as Turkey, will flourish due to the sanctions removal. In other words, the authors are willing to address the critical question of how obstacles and opportunities interact from an entrepreneurial standpoint. Are these impediments a valid reason for entrepreneurs' reluctance to invest in Iran? While the literature review highlights the difficulties associated with digitalisation and supply chain optimisation in developing countries (Anastasiadis et al., 2018), there is no evidence of cross-examination of opportunities and barriers from an entrepreneur perspective. Which factors significantly impact food value chain investment in developing countries, given equal weight to each barrier? The research focus is shifting away from supply chain and fundamental barriers and toward more sustainable and optimised agrifood production as modern countries' priorities shift (Pérez-Mesa et al., 2021). Thus, does this mentality and emphasis on priority setting make sense in a developing country like Iran?

It is worth noting that a lateralised examination of opportunities or obstacles is ineffective in real-world case studies. Thus, by considering the classification of barriers for entrepreneurs entering Iran's food industry and inter-level relationships between barriers through the multilayer decision-making strategy, this research suggests investment opportunities priorities for entrepreneurs in the agrifood sector in emerging economies. Moreover, following a thorough review of the pertinent literature regarding significant barriers and opportunities, a group of entrepreneurs in Iran's food industry was selected to assist the scholars in evaluating critical agrifood industry challenges. The mixed quantitative approach of ISM-MICMAC and DEMATEL methodology is used to prioritise and depict the significance of each criterion in Iran's entrepreneurial system. Therefore, this research aims to fill the gap

Following that, the results are thoroughly evaluated using a strength-weakness infrastructure to address the project's central question. It is anticipated that this research will establish a meaningful connection between criteria and provide significant managerial and academic insight that will complement subsequent research with a more specific objective.

\section{Literature Review}

The agri-food industry has traditionally been a commodity-driven industry, with homogeneous goods being prioritized to maximize economies of scale and productivity (Ho et al., 2018). Due to tightly controlled distribution channels, market rules, or limited production resources, the food industry has not been required to add value to agricultural products in the past (Lindgreen et al., 2012). Food markets have been successful in massproducing homogeneous products at a low cost. However, as customer demand for highquality goods has grown due to technological advancements, increased competition, and 
simplified products, demand for differentiated products has also grown (Cotes-Torres et al., 2016). As a result, businesses have ramped up their value-added activities to meet customer demands (Zhao et al., 2019). The concept of agri-food entrepreneurship, closely related to the value chain concept, has emerged as the relationship between customer experience and agricultural products has grown stronger (Dung et al., 2020). In agri-food entrepreneurship, the value chain paradigm is helpful for project identification, formulation, and strategy development (Rich et al., 2011). The literature review addresses the value chain as a ploy made by a company to an existing product's shape, timing, or location to increase its marketability (Mihailovi and Jean-Radi, 2019). In agriculture, added value is defined as increasing the economic value of a product, such as wheat, by processing it into another product, such as flour, that the customer requires for baking bread (Sánchez-Borrego et al., 2021). By examining the interdependence of various actors at each stage, value chain approaches are used to identify actions in highly dynamic markets in developing countries (Bolwig et al., 2010). The food value chain is divided into four major stages, inputs and equipment, production, product processing, and distribution (Pacheco and Urbano, 2019).

According to previous research, processing, packaging, shipping, and selling have the most entrepreneurial opportunities in the food value chain (Kuckertz et al., 2019). As one of the most profitable parts of the value chain, agricultural processing products would increase production costs while decreasing profit margins (Jafari-Sadeghi, 2020). Since paradigms like innovation, open innovation, and knowledge management in packaging and processing foods increase a company's overall competitive advantage, this stage is by far the most knowledgebased part of the value chain (Meynard et al., 2017). In recent years, several terms such as coinnovation (Bitzer and Bijman, 2015), innovative enablers, and barriers to achieving such a mindset have been studied (Petridis et al., 2020). For a higher chance of knowledge management, businesses should implement a concise and continuous knowledge flow between internal departments and collaborate with other companies if they are willing to complete this stage (Brun et al., 2021). Due to sanctions, Iran has been unable to implement top-rated infrastructures such as SAP in managing supply chains or marketing tools such as MOZ or Hootsuite in recent years (Heshmati and Dibaji, 2019). Furthermore, using modified production technologies to develop new value-added products would allow entrepreneurs to differentiate their business models and innovate. According to a recent study on the value chain impact in food packaging in Malaysian SMEs, innovation and creativity significantly impact consumer behaviour and purchase frequency (Abidin and Suradi, 2014).

Due to challenges after production, research has revealed untapped entrepreneurial opportunities in the food value chain distribution sector (Anastasiadis and Poole, 2015). According to research, the value chain is severely disrupted due to the poor relationship between farmers and market players, insufficient infrastructure, and inadequate governance systems (Jensen and Orfila, 2021). Furthermore, governments' restricted political and economic relationships harm the supply chain's efficiency and responsiveness (Halabi and Lin, 2017). As a result of these factors, the value chain's distribution sector suffers (Sen and Kansal, 2019). Non-supportive regulations and a lack of financial support for entrepreneurship in developing countries are among the most glaring reasons why agri-food 
investors are less eager to expand their businesses in developing countries, according to a case study (Gachukia, 2016). Entrepreneurs will assess the link between productive activities and provide a framework for finding their competitive advantage and potential risks in investments by looking at the value chain in the agri-food sector (Fagioli et al., 2017). Entrepreneurial opportunities and threats in the food value chain are often overlooked, but they are at the heart of the most critical decisions that lead to new business ventures (Kamariotou et al., 2019). The agricultural supply chain's decision-making systems and frameworks have been designed to reduce risk and improve overall functionality (Fagundes et al., 2020).

In general, the agri-food business model comprises four levels that entrepreneurs must carefully evaluate before writing their strategic plans. To begin with, several cultural, healthawareness and raw material availability factors influence the errant demand pattern in developing countries (Nixon and Ramaswami, 2018). As previously stated, demand patterns significantly impact environmental changes in countries like Iran (M. Karimi et al., 2020). For example, an American case study shows that imposing a diet or any other health issue that necessitates a specific amount of product consumption every day causes demand to skyrocket in a short period (Englund et al., 2020). Furthermore, market research in new food packages shows that the soaring demand is in danger of plummeting and market share loss as new brands enter the market (Yildirim et al., 2018). As a result, an Arabic case study on organic food products suggests that to adjust and analyze demand in developing countries, keeping the demand rate at a certain level and designing an unprecedented marketing plan focusing on customer behaviour is recommended (Muhummad et al., 2016). Second, in such countries, raw material and logistics supply is a critical issue. The logistics sector in developing countries is one of the most ineffective, preventing product availability to consumers even after proper package design and production (Kach and Borzabad, 2011). Political issues such as sanctions and the high rate of transfer of raw materials such as flavours from foreign suppliers should also be considered (Nagoev et al., 2020). According to (Wall and Chen, 2018), the marketing and penetration level of introducing a product, known as information asymmetries, must be effectively designed. According to pragmatism research, both farmers and customers need to be educated, and several experiments have been conducted in this area in recent years (O'Donoghue and Heanue, 2018). The findings show a higher rate of brand loyalty and a more frequent purchase pattern for newly introduced products to the market. Finally, environmental changes brought on by government decisions or natural disasters significantly impact food entrepreneurship (Ortega-Dela Cruz, 2020).

Entrepreneurial opportunities exist primarily as a result of changes in demand in the processing and manufacturing sectors. Simultaneously, inputs and equipment are driven more by exogenous market shocks, such as climate change and global population expansion (Sen and Kansal, 2019), which necessitates increased production efficiency. Smart farming and automation are essential components in assisting the agri-food industry in managing sustainability. Numerous tools, including sophisticated data analysis and sensors, are used to ensure the precise application of pesticides, herbicides, and fertilisers. Additionally, vertical farming has been considered an effective strategy for increasing output sustainability (Benke 
and Tomkins, 2017). Additional in-depth analyses demonstrate that an entrepreneurial impediment does not originate from a single source (Rodrigo et al., 2015). Nevertheless, the compulsion to access technological developments in process engineering and biotechnology results in inefficiencies in augmenting the raw and finished product, posing various secondary dangers to entrepreneurs. For instance, ineffective environmental pollution management and a lack of awareness resulting in demand shifts.

One of Iran's agribusiness challenges is that intermediaries typically add no value to the product but raise its price. The inefficiency of the supply chain system results in a narrowing of the value chain. As a result of this inefficiency, profits in the intermediation sector are reduced, and profits are accumulated, increasing the tendency toward intermediation rather than production and decreasing the incentive for entrepreneurs to enter. Low-quality seeds, unjust domestic and export markets, inefficient services, ineffective market management, and product devaluation throughout the value chain contribute to the value chain's failure in the processing and converting sector (According to published reports of The Ministry of Agriculture Jihad of Iran).

To summarise the problems mentioned above, Figure 1 illustrates the hurdles to entrepreneurship in underdeveloped nations alongside the opportunity resources and facilitators. In this chart, the assets and infrastructure $\left(\mathrm{B}_{1}\right)$ criteria are defined as entrepreneurs' limited access to several cardinal assets, such as transportation modes that have been developed efficiently through digitalisation in modern countries (Mulyati and Utami, 2020) or several other thoughtful transportation planning and algorithms that have been proposed to reduce costs in this logistics (Karami and Kashef, 2020). On the contrary, the absence of multimodal and intermodal transportation systems, a widely adopted technique in EU member states, is a significant hurdle for investors. Additionally, the transportation system's constraints in handling borders and ports (Karimi et al., 2019) are a critical shortcoming that should be addressed and analysed in these nations. The second component is supposed to be technological advancement $\left(\mathrm{B}_{2}\right)$ and the availability of contemporary technology to transform traditional farming into a more efficient business (Ronteltap et al., 2016). Additionally, the word is used as an instructional tool to explain farmers' access to the internet and other related learning resources (MacAuley and Niewolny, 2016). The literature demonstrates that impermeable workers in business do not significantly alter their thinking when it comes to traditional agriculture. Thus, based on a Swiss dairy industry case study, the farmer's perspective in the destination country should also be included when calculating success rates (Schwendner et al., 2020). The third term is supply chain efficiency (B3), which scholars in various domains have extensively studied. For instance, a case study from Ukraine illustrates the logistics difficulties that exist in a modern economy (Kush et al., 2020). Meanwhile, a hot topic for bolstering supply chain performance has been adopting blockchain technology and more innovative trading procedures (Saurabh and Dey, 2021). This phenomenon explores the concept of getting the correct product to the appropriate place in the shortest amount of time and at the lowest possible cost. Numerous studies have exaggerated Iran's supply chain problems, and entrepreneurs must shed light on such inefficiency (Khalilpourazari et al., 2020). 


\section{Insert Figure 1}

Besides, supply chain responsiveness $\left(\mathrm{B}_{4}\right)$ refers to the supply chain's ability to respond meaningfully and appropriately to consumer requests or market changes, including the inflexibility of the agri-food supply chain (Asamoah et al., 2021). In recent years, scientists have emphasised responsiveness in trade functionality and its impact on competitive advantage creation (Ayoub and Abdallah, 2019). Following that, the agricultural business sector is becoming increasingly concerned with sustainability, commonly defined as operations that reduce the danger of environmental pollution and damage to natural ecosystems (Bryceson and Ross, 2020). However, the term "sustainability" has been deconstructed into more particular difficulties in recent years, notwithstanding the literature's emphasis on environmental stewardship $\left(\mathrm{B}_{5}\right)$, social responsibility $\left(\mathrm{B}_{6}\right)$, and economic sustainability $\left(\mathrm{B}_{7}\right)$. Several scientists take a unique approach to the social dimension of sustainability, emphasising cultural norms (Maizza et al., 2019), whereas several eco-social studies focus on the critical impacting indicators along the agri-food value chain (OterosRozas et al., 2019). As previously stated, the business has become knowledge-based, and it has been demonstrated that organisations who prioritise knowledge exchange, innovation, and packaging have a greater chance of market success (Finco et al., 2018). As a result, knowledge management $\left(\mathrm{B}_{8}\right)$ and innovation $\left(\mathrm{B}_{9}\right)$ are open to evaluation within this framework to better understand their crucial roles in agricultural entrepreneurship. Finally, other structural issues such as human resource costs, laws, and government subsidies influence the business owner's decision to invest in a particular location (Di Pietro et al., 2021).

Additionally, the high incidence of organisational corruption and rigid acquisition rules discourage businesses from investing in some countries (Fiankor et al., 2019). Therefore, these characteristics are classified as government assistance and flexible rules ( $\left.\mathrm{B}_{10}\right)$ and regional and global economies $\left(\mathrm{B}_{11}\right)$, which will be evaluated more precisely later in this article using a qualitative approach. The insights obtained from the investigation, despite the limitations and sanctions, aid foreign investors to be aware of the legal obstacles and transaction restrictions associated with conducting business in this country (Safari, 2018).

\section{Methodology}

In this section, an overview of the research framework has been provided. All issues, including the data gathering, methods and analysis, have been illustrated in upcoming sections. Figure 2 present the research steps in an integrated fashion.

\section{Insert Figure 2}

Phase (1) Barriers Identification. The researchers searched various databases, including Scopus, ScienceDirect, Google Scholar, and ProQuest, using keywords such as Barriers, Opportunities, and Enablers for International Entrepreneurs in the Agri-Food Sector. Using these searches, the authors aimed to extract the hurdles to investigating the agri-food market for IEs in Iran's growing economy. After identifying the initial barriers, the authors reviewed 
the list for commonalities and the possibility of merging some hurdles. As a result, the final list of barriers to IE investment in the agri-food industry in Iran's growing economy is shown in Table 1. It should be noted that these barriers were discussed in the literature review part.

\section{Insert Table 1}

Phase (2) Data Gathering. Initially, the list of IEs was identified during this stage. These experts were chosen based on their expertise, education, experience in the agri-food industry/sector, international experience, and entrepreneurial experience, among other qualifications. The scholars selected the experts using a judgmental and snowball sampling approach based on these qualifications. As a result, 15 IEs participated in the data collection stage of this research. As the authors are using export-oriented methods and MCDM approaches, the number of participants in these types of research usually varies between 3 to 15. Thus using this number of experts in decision-making articles is famous among scholars (e.g. Wen et al., 2021; Amiri et al., 2021). The expert profiles who took part in this study are included in Table 2.

\section{Insert Table 2}

According to the above table, three groups of experts participated in this research, including industry experts in the agri-food sector, officials and authorities in the agri-food industry from the government and policy-making organizations, and academicians from universities or research centres. These experts participated in this research in two phases. First, they analyzed how each barrier leads to the others for the ISM-MICMAC stage. They completed a semi-triangular-based matrix as a questionnaire to identify how each barrier leads others by using relevant symbols, including A, V, O and X (Jafari-Sadeghi et al., 2021a; 2021c). Note that for this stage, all 15 IEs were gathered via an online meeting by MSTEAMS and completed the questionnaire for ISM-MICMAC as one panel after a discussion on each question. In this three-hour online meeting, the scholars also participated as facilitators and mentors for possible terms and method queries (Boudlaei et al., 2020). In total, 55 questions were answered by the panel for this section.

- If barrier (i) leads to the barrier (j), then the IE panel selects (V),

- If barrier (j) leads to the barrier (i), then the IE panel selects (A),

- If barrier ( $i$ ) leads to the barrier (j) and vice versa, then the IE panel selects $(X)$,

- If barrier (i) does not lead to the barrier (j) and vice versa, then the IE panel selects (O),

- $\quad$ The main diagonal of the matrix is filled by (X) (Kumar et al., 2021).

The IEs completed the DEMATAL-ANP questionnaire as part of the second phase. The matrix-based questionnaire at this level included the eleven impediments. It was asked to rate the impact of each barrier on the other on a nine-point Likert scale, which included very very high; extremely high; high; nearly high; neither high nor low; nearly low, low, very low; exceptionally very low (Hashemi et al., 2021). The fundamental question was how each IE believes that one of the obstacles $\left(\mathrm{B}_{1}\right.$ to $\left.\mathrm{B}_{11}\right)$ influences the other barriers $\left(\mathrm{B}_{1}\right.$ to $\left.\mathrm{B}_{11}\right)$. Each IE 
was asked 110 questions as an expert to complete the matrix-based questionnaire in this section. The questionnaire was distributed through email and received responses from experts within three weeks, with each questionnaire taking an average of 2.5 hours to complete. Table 3 converts the aforementioned linguistic variables to numerical values.

\section{Insert Table 3}

Phase (3) Analysis. This section is divided into two key sections: ISM-MICMAC, which is used to classify barriers and present a conceptual model, and DEMATEL-ANP, used to determine the barriers' causal relationships and relevance. The following sections describe each of these two sub-parts. Numerous models with varying purposes exist in expert-based multiple-criteria decision-making (MCDM) techniques. Specific models are geared toward multi-attribute decision making (MADM), while others are geared toward multi-objective decision making (MODM) (Mokhtarzadeh et al., 2021). This article aims to apply MADM methodologies to the research objectives stated in the introduction section. Numerous models exist in the MADM era, and they can be classified into three broad categories. To begin, approaches whose primary purpose is to quantify the significance of specific criteria or factors (e.g., Analytical Hierarchical Process (AHP), Analytical Network Process (ANP) or Best-Worst Method (BWM). Second, specific methods are geared at ranking and sorting alternatives based on a variety of criteria (e.g., simple additive weight (SAW), Technique for Ordering Preferences by Similarities to Ideal Solution (TOPSIS), and Simultaneous Evaluation of Criteria and Alternatives (SECA), among others). Thirdly, some methods, such as Interpretive Structural Modeling (ISM), Decision Making Trial and Evaluation Laboratory (DEMATEL), are geared toward establishing relationships between criteria/factors/themes (Jafari Sadeghi et al., 2021b). As the two primary objectives of this research are (1) classifying the barriers and presenting a level-based conceptual model, and (2) comprehending the causal relationship between the barriers and determining their significance for improved decision-making by international entrepreneurs in Iran's agri-food sector, the first and second groups of MADM methods are appropriate. Finally, Table 4 has been presented to show recent agri-food research using MCDM methodologies. Thus, the authors chose the ISM-MICMAC and DEMATEL-ANP for the two study objectives, respectively, based on their popularity, proximity to the research objectives, and a better knowledge of the IEs and experts participated in this research. These techniques have been described in detail in the following sections.

\section{Insert Table 4}

\section{Phase (3.1) ISM-MICMAC}

Numerous ways exist for comprehending the relationship between barriers, criteria, challenges, hurdles, or any other feature. Several methods, such as Structural Equation Modelling (SEM) (Mustafa et al., 2020; Mahdiraji et al., 2021), are based on statistics and require access to real-world data. However, the authors had no data addressing these quantitative barriers in their study, and no numerical data existed in Iran's rising economy in the agri-food sector. Thus, the authors used the ISM-MICMAC framework to classify the 
obstacles to investment in the agri-food sector of emerging economies and developed a conceptual model to illustrate the interaction between these barriers (Shanker and Barve, 2021). The following are the steps in this procedure.

Step (1) Barriers Extraction. After identifying the barriers, the relevant semi-triangularmatrix-based questionnaire is designed and completed by the expert panel and described previously. The expert panels used the five rules mentioned in Phase 2 to complete the questionnaire, and then the research team gathered the completed forms.

Step (2) Full Reachability Matrix (FRM). Each code (such as A, V, X, and O) is converted to binary values using its own set of rules. Where (V) and (X) are assigned "one" and (A) and (O) are assigned "zero." As a result of this, the Zero and One Matrix (ZOM) is formed (Bux et al., 2020). To improve the robustness of the gathered data, the validity of the expert opinions is scrutinized for inconsistencies; thus, a possible revision of the ZOM is carried out to create a more reliable matrix for further investigation, dubbed the Full Reachability Matrix (FRM). This logic (transitory/transitivity check) is simple: "If barrier (A) leads to the barrier (B), and barrier (B) leads to the barrier (C), then a barrier (A) leads to the barrier (C)." If the experts ignore this rule, a transitivity relationship exists, and the notation $\left(1^{*}\right)$ is used in ZOM cells instead of zero. As a result, the FRM is a square $\mathrm{n} \times \mathrm{n}$ matrix with the same row and column values as the I (row) and $\mathrm{j}$ (column) variables (column). This rule was coded in MATLAB and implemented on the ZOM matrix due to many barriers in this study (Singh et al., 2020).

Step (3) Classification by Driver-Dependent Power Map (DDPM). In this step, known as "Matrice d'Impacts Croises Multiplication Appliquee a un Classement" or cross-impact matrix multiplication applied to classification (MICMAC) (Trivedi et al., 2021); first, the driver (DR) and dependence (DE) power of the barriers are measured using the following equations (Jafari-Sadeghi et al., 2021 a; 2021d).

$\begin{array}{ll}\operatorname{DR}(\mathbf{i})=\mathbf{a}_{\mathbf{i} \cdot}=\sum_{\mathbf{j}=\mathbf{1}}^{\mathbf{n}} \mathbf{a}_{\mathbf{i j}} & \forall_{\mathbf{i}, \mathbf{j} \in \mathbf{n}} \\ \operatorname{DE}(\mathbf{j})=\mathbf{a}_{\cdot \mathbf{j}}=\sum_{\mathbf{i}=\mathbf{1}}^{\mathbf{m}} \mathbf{a}_{\mathbf{i j}} & \forall_{\mathbf{i}, \mathbf{j} \in \mathbf{n}}\end{array}$

Where DR(i) denotes the driver power barrier, $i$ and $\mathrm{DE}(\mathrm{j})$ present the dependent power of the same barriers, and aij reveals the value of the FRM matrix. Based on the DR and DE values, a power map emanates and classifies the barriers into four groups according to the following rules (Sonar et al., 2020):

- Dependent barriers with low DR and high DE,

- Driver barriers with high DR and low DE,

- Linkage barriers with high DR and high DE,

- Autonomous barriers with low DR and low DE,

Step (4). Level Based Conceptual Modelling. Given a large number of barriers (eleven), this step was performed using the MATLAB software according to the following guidelines (Jafari-Sadeghi et al., 2021a). 
- Identify the reachability barriers (i) by those that are affected by the barrier (i) and have received value (1) in the $i^{\text {th }}$ row,

- Identify the antecedent barriers (i) by determining those that affect the barrier (i) and have received value (1) in the $j^{\text {th }}$ column,

- Identify the intersection barriers (i) by determining barriers that are reachable and also antecedent and have value (1) in both row and column,

- If the intersection and reachability set is equal for barrier (i), then consider that barrier as a high-level barrier and eliminate it from the FRM.

- Repeat the above activities until all barriers are leveled and the conceptual model emanates.

\section{Phase (3.2) DEMATEL-ANP (DANP)}

As previously mentioned, amongst the methods of MADM to analyze the relationship of factors, barriers or challenges, the DEMATEL method is so popular and has been employed by other scholars frequently for different purposes (e.g. Garg, 2021; Du and Li, 2021). The merit of this method is to provide a causal relationship amongst the barriers and provide a network diagram indicating the causes vs the effects. Moreover, this method can be combined with other MADM weighting approaches such as ANP to determine the weight of analyzed barriers (Mubarik et al., 2021). As fifteen experts have completed the DEMATEL questionnaires, the average $Z_{i j}^{p}$ is calculated and then transferred to the DEMATEL quantitative matrix where the $Z_{i j}^{p}$ denotes the impact of barriers (i) over (j) from an expert (p) point of view. The following steps have been used for the DEMATEL-ANP method known as DANP.

Step (1) Initial Matrix. Linguistic variables are transferred to numerical values (according to Table 3), and the influence comparison scale for each barrier is defined. Then, the pairwise influence relationship $n \times n$ matrix is measured by the average $Z_{i j}$ value as follows. Where $(\mathrm{P})$ is the number of IEs experts who participated in this research.

$Z_{i j}=\frac{1}{p}\left(Z_{i j}^{1}+Z_{i j}^{2}+\cdots+Z_{i j}^{p}\right)$

Step (2) Normalization. The normalized direct-relation matrix known as $(\mathrm{N})$ is formulated using the following equations. Where (s) is the normalized constant and emanated from equation $(3)$ and $(Z)$ is the initial average matrix emanated from step 1.

$s=\operatorname{Min}\left\{\frac{1}{\max _{1 \leq i \leq n} \sum_{j}^{n} z_{i j}}, \frac{1}{\max _{1 \leq j \leq n} \sum_{i}^{n} z_{i j}}\right\} \quad ; \quad \forall_{i j}=1,2, \ldots, n$

$N=s \times Z$

Step (3) Total Relationship Matrix. This matrix, denoted as (T) (to avoid confusion with the total reachability matrix in the ISM method), is obtained by solving equation (6) in the MATLAB 2020b software. 
$T=N+N^{2}+N^{2}+\cdots=\sum_{i=1}^{\infty} N^{i}=N \times(I-N)^{-1}$

Step (4) Identifying the cause/effect and power. The sum is calculated in each row and column for each barrier to determine the total impact and deter. The results presented by $\left(\mathrm{R}_{\mathrm{i}}\right)$ and $\left(D_{j}\right)$ describe the direct and indirect effect of each barrier for IEs to invest in the agri-food of the emerging economy of Iran.

$R_{i}=\sum_{j=1}^{n} t_{i j} \quad ; \forall_{i}$

$D_{j}=\sum_{i=1}^{n} t_{i j} \quad ; \forall_{j}$

The net effect $\left(E_{i}\right)$ and the overall prominence $\left(P_{i}\right)$ for each barrier was measures by equations (9) and (10).

$P_{i}=\left\{R_{i}+D_{j} \mid i=j\right\}$

$E_{i}=\left\{R_{i}-D_{j} \mid i=j\right\}$

The higher value of $\left(P_{i}\right)$ determines the more impact of the barrier. Moreover, the positive or negative value of $\left(E_{i}\right)$ presents the cause or effect of the barrier, respectively (Ghosh et al., 2021). Eventually, the network map reveals the causal relationship of the barriers for IEs to invest in the agri-food sector of the emerging economy of Iran (Hashemi et al., 2021).

Step (5) Measuring Barriers Importance. The following steps have been linked to the outputs of the DEMATEL section to investigate the importance of each barrier and possibly classify them based on their final scores in this research to measure the importance of each barrier. To begin, the normalized $\mathrm{C}^{\mathrm{H}}$ matrix is calculated by dividing each row in the total relationship matrix $(\mathrm{T})$ by the sum of the rows $(\mathrm{S} \mathrm{i})$.

$C^{H}=\left[\begin{array}{ccc}T_{11} & \ldots & T_{1 n} \\ T_{21} & \ldots & T_{2 n} \\ T_{m 1} & \ldots & T_{m n}\end{array}\right] S_{m}$

Where $S_{i}=\sum_{j=m}^{1} T_{i j}$ and $m=n$

Then, to obtain the unweighted supermatrix, the $C^{H}$ is transposed and called $F^{m}=\left(C^{H}\right)^{\prime}$. Then, by limiting the supermatrix the overall importance of each barrier is measured by the following formula.

$W^{\text {limit }}=\lim _{k \rightarrow \infty}\left(C^{H^{\prime}}\right)^{k}$

The obtained results from the $W^{\text {limit }}$ produces the DANP weights. These scores are sorted to achieve the rank of each barrier in this research and classify them according to the quartile of their final weights.

\section{Findings and Results}

After completing Phase I and compiling a list of impediments to IE investment in the agrifood sector in Iran's emerging economy (Table 1), a multi-layer decision-making approach 
incorporating ISM-MICMAC and DANP was used. This section illustrates the results. These findings are based on the expertise of participated in this research and were previously described in Table 2. The research's results and findings are presented in two distinct sections. The ISM-MICMAC outputs are illustrated first, followed by the DEMATEL-ANP findings.

\subsection{ISM-MICMAC findings}

As illustrated in Figure 2 and described in greater detail in section (3.1), the ISM-MICMAC method was used in this study after a questionnaire was gathered from the 15 agri-food IEs. They participated in this research as experts. The initial ISM questionnaire was completed in this first step, following a three-hour online meeting with the expert panel (Table 5a). After transferring the values to ZOM, the transitivity check and logic are implemented, and the FRM (final reachability matrix) is generated and presented in Table 5b.

\section{Insert Table 5}

Each barrier's driver and associated power have been determined and are presented in the last column and row of the preceding table using formulas 1 and 2. As is evident, the DDPM has a maximum value of 11 . (the maximum number of considered barriers). The barriers are classified according to the DDPM map in Figure 3.

\section{$\underline{\text { Insert Figure } 3}$}

Following the MICMAC stage, the ISM approach was used to implement the spet (4) algorithm described in Section (3.1), and the barriers were classified into three distinct categories after three runs. As shown in the map above, the majority of the barriers are classified as linkages, with three classified as dependent and autonomous. This demonstrates that linkage barriers are the primary impediment to IEs investing in the agri-food sector of Iran's emerging economy. Table 6 summarizes the ISM findings.

\section{$\underline{\text { Insert Table } 6}$}

By using a creative design and linking the levels together according to Table 6 , the initial level-based model resulted from ISM is presented in Figure 4.

\section{$\underline{\text { Insert Figure } 4}$}

\subsection{DEMATEL-ANP findings}

This section discusses the causal relationship between the barriers and their importance after classifying them using MICMAC and providing and designing a level-based conceptual model using the ISM approach. To accomplish this, the DANP hybrid DEMATEL-ANP method, as described in the section, was used (3.2). To begin, questionnaires were given to each of the 15 IEs experts. Following the completion and collection of completed questionnaires, the linguistic variables were converted to numerical values following Table 7 , and the average value of the expert opinions was calculated using equation (3). The 
DEMATEL matrix is then normalized using equations (4) and (5), and the total relationship matrix, denoted by $(\mathrm{T})$, is calculated using equation (6).

\section{$\underline{\text { Insert Table } 7}$}

As indicated in the preceding table, cells highlighted in green indicate correlations more significant than the average value (threshold value) that warrant further analysis. The subsequent stage quantifies and presents each barrier's direct and indirect impact or effect, denoted by $\mathrm{R}$ (equation 7) and $\mathrm{D}$ (equation 8). (equation 8). Notably, Table 8 also includes the impact of each barrier $(\mathrm{P}=\mathrm{D}+\mathrm{R})$ as calculated by Eq. $(9)$ and the cause or effect of each barrier (E=R-D) as calculated by Eq.(10).

\section{$\underline{\text { Insert Table 8 }}$}

Five effects and six causes were identified based on the preceding table, and their locations on the network relationship map are depicted in Figure 5.

\section{$\underline{\text { Insert Figure } 5}$}

After implementing the DEMATEL method and identifying the causes and effects and the relationship amongst the barriers of entering the Agri-food sector in Iran by IEs, the importance of each of these barriers was also measured by the ANP method based on the total relationship matrix presented in Table 9 and equations (11) and (12). Note that the weights of the barriers resulted after three times applying equation (12).

\section{Insert Table 9}

It is clear from the above table that barriers 3,5,7, and 11 have the highest importance, then barriers number 1,2,4 and 10; eventually, barriers number 6,8 and 9 have the lowest importance according to the results.

\section{Discussion and Implications}

The ISM levelling diagram displays the first level's environmental management, directly related to the effectiveness and responsiveness of the supply chain. This outcome is consistent with (Filippi and Chapdaniel, 2021) research findings indicating the effectiveness of organisational knowledge management in conjunction with supply chain sustainability. Our findings, however, indicate that information flow inside an organisation is the primary factor affecting supply chain effectiveness. As a result, future studies should focus on the primary drivers of information flow in SMEs. According to our findings in the ISM levelling figure, as a symbol of a rising country, the Iranian government should validate accessible technologies and foster an entrepreneurial period in Iran.

We classified the barriers into eleven broad categories in general. What makes this passage even more astonishing is the influence and direct relationship between six criteria in this research's third level. As previously said, the assets and technology are inextricably linked. These impediments are inextricably linked to how governments allocate resources to entrepreneurship. Additionally, our findings suggest that bolstering these elements 
encourages corporate innovation and makes production more environmentally friendly. It is clear that encouraging governments and removing barriers to sustainability positively affect economic progress in Iran. A study by (Hysa et al., 2020) demonstrates a direct correlation between these variables. However, there is no indication that Iran's government is capable of encouraging agri-food investment. The DEMATEL results indicate that Iranian organisations must improve their agility and information-sharing capabilities. As a result of this transformation, likely, the supply chain component at the second level of our results with the highest cause rank would be optimised. While several researchers, such as (Ginting et al., 2020), have projected the effect of knowledge management on overall supply chain performance, we believe that knowledge sharing, innovation, and other factors such as digitisation, as advocated by (Schniederjans et al., 2020), should be studied more systematically. As a result, the authors propose that future research become more focused and systematic, rather than broad, to acquire insights that may be applied in both academia and industry concurrently.

Our primary objective was to conduct a thorough review of agri-food industry investment and identify the primary constraints and opportunities in a rising economy like Iran. The passage's succinct conclusion is that managers in Iran, for example, must embrace cutting-edge technological tools such as scrum, which has been explored in the literature as a modern method for capturing and sharing information inside an organisation (Korimbocus et al., 2019). Without question, social media and team management software across several platforms have simplified document sharing and team decision-making in recent years (Dahri and Yunus, 2018). Additionally, one of the entrepreneurs' key concerns has constantly been adapting organisational ethics to the culture of a foreign country. As a result of our findings and the critical nature of increasing knowledge sharing across organisations, which affects other barriers to entrepreneurship, foreign investors must budget enough for knowledge sharing system enhancement. According to the results at the top level of the ISM conceptual model and the experts' emphasis on waste management during our online discussions, managers must identify ways to make production operations more sustainable. In addition to the domestic supply chain of each product, international supply chains are also crucial in trade balance and food security. Differences in economics, legislation, standards and regulations in each chain determine the challenges in supply chain management. Developing countries, such as Iran, are the leading suppliers of raw materials to international supply chains; therefore, the creation of supply chains can significantly impact the economies of these countries. While developed countries, due to consumer pressure, seek stability and optimisation of supply chains, so the creation of supply chains following national goals and then optimisation of these chains can play a significant role in the development of agriculture.

Supply chain sustainability can be pursued in three dimensions: economic, social and environmental, to achieve an efficient relationship between supply chain members. The efficiency index of a chain is determined by the level of consumer satisfaction, which increases the competition between suppliers, and ultimately, access to a comfortable product, high quality and reasonable price will be achieved.

Our findings demonstrate the importance of managers initially focusing on the economic side. Budget allocations in this section should be used to invest in environmental sustainability. As a result, managers would be able to observe the impact of their activities on social behaviour. Our findings demonstrate that the expert's opinion contradicts a widely held 
belief that the region's markets are unavailable due to sanctions or other political constraints. Numerous studies have emphasised the necessity of an excellent regional market as a justification for avoiding investing in Iran. However, this study demonstrates that managers have the tiniest concern for the regional market. They should devote all of their efforts to enhancing knowledge flow to ensure supply chain sustainability and responsiveness.

\section{Insert Figure 6}

Finally, it is worth noting that recent studies conducted within the previous decade, as noted earlier in the article, were conducted with opportunistic and conservative attitudes. Each side, as seen in Figure 6, is evaluated primarily based on five criteria. The authors offer a tradeoff between two viewpoints for additional management consequences with a strategic perspective based on the findings of this research. $\mathrm{C}_{3}$ was the highest ranking in this study because managers lacked waste management in agri-food production. As a result of the literature analysis, $\mathrm{C}_{8}$ was identified as an opportunity due to its ability to aid managers in reducing expenses and recycling food wastes. As a result of the $\mathrm{C} 3, \mathrm{C} 8$ tradeoff, managers are urged to place a premium on environmental and sustainability management in agri-food projects. Additionally, our data demonstrate that improving $\mathrm{C}_{2}$ as a barrier is the noblest effect of other factor changes. Thus, demand unpredictability and erroneous supply volume were included to regulate and normalise the overall performance of the agri-food supply chain. Accordingly, supply chain managers should maintain control of oversupply and demand volumes regardless of the priorities identified in this research. They should do so with a systematic attitude and by considering $\mathrm{C}_{1}, \mathrm{C}_{6}$, and $\mathrm{C}_{7}$. Our findings indicated that knowledge and innovation were significant elements in this study. As previously said, the Iranian culture and behaviour regarding the acceptance of new products in the market on the one hand, and the farmers' obstinate worldview on the other, necessitate knowledge sharing and education. Critical communications that may exist between members have not been established due to a lack of infrastructure. For example, in developed countries, industrial farms have a brand, and the product presented in stores is known as the relevant farm brand, which attracts entrepreneurs and adds value in various parts of the chain, including processing and packaging.

Nonetheless, administrators of the $\mathrm{C}_{4}$ and $\mathrm{C}_{10}$ must invest in a massive marketing campaign to change farmer and consumer perceptions of the new crop. Semi-private and private enterprises operating in agriculture can manage agricultural supply chains, which results from the economic structure and relative independence from the government. A single startup can manage the supply chain of agricultural products from the supply of seeds, water, fertilizer, and other inputs to reach the consumer. Its optimization by choosing the best communication between members will significantly impact the stability of the product chain. Governments play a critical role in attracting foreign investment by relaxing regulatory requirements and providing financial assistance to entrepreneurs. Iranian efforts must be cognizant of the immediate benefits of cooperation with international investors, such as job creation or GDP growth, as a long-term effect in this business. For example, corporations are compelled to alter their formulas to accommodate regional preferences in the beverage sector. Thus, regarding $\mathrm{C}_{10}, \mathrm{C}_{5}$, and $\mathrm{C}_{9}$, government actions should facilitate business in Iran and remove existing impediments to stimulate entrepreneur investment. It improves the Iranian way of life and addresses one of the most severe problems facing the modern economy: 
unemployment. According to the examination of the literature, the present trend indicates that scientists take a position when projecting the hurdles and opportunities associated with agrifood investment. This paradigm should be reimagined as a consistent and balanced way of thinking to assist managers in making the optimal investment decisions in a country with a developing economy. The authors argue that scientists should participate in such investigations more regularly because taking a position biases managers and efforts in this business toward making alternative decisions. Based on the literature review, the current trend shows that scientists take a side in projecting the barriers and opportunities in agri-food investment. This paradigm should be revamped into a congruous and evenhanded thought to aid managers in making the best decisions for investing in a country with an emerging economy. The authors believe that scientists should contribute to such studies more frequently since taking sides biases both managers and initiatives for making different decisions in this industry.

\section{Conclusion and Future Recommendations}

Unfortunately, in Iran's emerging economy, supply chain management, despite its high importance, has not been considered a strategic method in the country's macro-economy. Especially in the agricultural sector, where there is an excellent variety in supply chains. The first step in supply chain management is scientific analysis. The purpose of this analysis is (1) to find the main players in the value chain, their links and their role in the chain, (2) to determine the amount of value-added for each product at each stage, and (3) to determine the opportunities and threats in the supply chain. This scientific analysis will help create double added value, increase the productivity of chain employees, create profits, create competition, improve customer service and increase production, which attracts entrepreneurs.

The list of barriers to entry for IEs into new markets and industries was culled from an examination of the agri-food sector's literature. Following that, a multi-layer decision-making approach comprised of ISM, DEMATEL, MICMAC, and ANP was used to address the following research objectives (1) classifying the barriers to entry into Iran's agri-food sector through the use of MICMAC; (2) comprehending the level-based relationships among the barriers through the use of ISM.

While this research is valuable and productive for a large number of IEs and authorities in the agri-food sector, all research has limitations. As an illustration, the research's findings and barriers were based on the opinions of IEs in Iran's growing economy and extrapolated to other regions. Countries with varying political regimes or economic development rates warrant additional examination. Additionally, the number of experts included in this study was limited by time and access constraints. Clearly, by involving additional experts, particularly IEs from outside Iran's growing economy, the results could have been different, as the input to the multi-layer decision-making approach was wholly dependent on the IEs' viewpoint.

From a technical standpoint, our proposed technique has some drawbacks. To begin, the hybrid decision-making technique used in this research, which included ISM, DANP, and MICMAC, was all based on discrete values and deterministic parameters appropriate for 
particular scenarios. However, as we all know, market uncertainty, particularly in the agrifood sector, is a contentious topic. Thus, it is proposed that future research incorporates uncertainty approaches and values such as interval, grey, fuzzy, hesitant fuzzy, intervalvalued fuzzy, intuitionistic fuzzy, and Pythagorean fuzzy into the decision-making process recommended in this article. Additionally, all of these decision-making approaches were informed by qualitative criteria scored by IEs as experts; however, quantitative indicators for some of these criteria, such as sustainability pillars indicators, infrastructures, and technology readiness level, are available in several developed countries and regions. Thus, it is strongly recommended that when quantitative measures are available for these circumstances, scholars employ statistical models such as multiple fuzzy regression analysis, structural equation modelling (SEM), and others for further investigation and benchmarking against the findings of this research. Finally, the multi-layer decision-making strategy employed in this study is interchangeable with various alternative methodologies available in the MCDM period. Perhaps substituting ISM, MICMAC, and DEMATEL is not feasible; nevertheless, for the ANP approach, other weighing methods, such as best-worst-method (BWM), Step-wise Weight Assessment Ratio Analysis (SWARA), and others, appear to be relevant. Notably, in this study, the weights and analyses of the barriers were addressed and requested from the IEs in a single round of data collection. Perhaps by adopting a more dynamic decision-making approach and utilizing techniques such as Markov chain analysis, we might inject more dynamism into financing decisions.

\section{References}

Al-Gamrh, B., Ku Ismail, K.N., Ahsan, T., and Alquhaif, A.(2020), "Investment opportunities, corporate governance quality, and firm performance in the UAE", Journal of Accounting in Emerging Economies, Vol.10, No. 2, pp. 261-276

Amiri, M., Hashemi-Tabatabaei, M., Ghahremanloo, M., Keshavarz-Ghorabaee, M., Zavadskas, E.K., and Banaitis, A. (2021), A new fuzzy BWM approach for evaluating and selecting a sustainable supplier in supply chain management. International Journal of Sustainable Development and World Ecology, Vol.28, No. 2, pp. 125-142.

Anastasiadis, F., and Poole, N.(2015), "Emergent supply chains in the agrifood sector: Insights from a whole chain approach", Supply Chain Management, Vol.20, No. 4, pp. 353-368.

Anastasiadis, F., Tsolakis, N., and Srai, J.S.(2018), "Digital technologies towards resource efficiency in the agrifood sector: Key challenges in developing countries", Sustainability (Switzerland), Vol.10, No. 2.

Apostolopoulos, N., Ratten, V., Petropoulos, D., Liargovas, P., and Anastasopoulou, E.(2021), "Agri-food sector and entrepreneurship during the COVID-19 crisis: A systematic literature review and research agenda", Strategic Change, Vol.30, No. 2, pp. 159-167.

Asamoah, D., Nuertey, D., Agyei-Owusu, B., and Akyeh, J.(2021), "The effect of supply chain responsiveness on customer development", International Journal of Logistics Management.

Ayoub, H.F., and Abdallah, A.B. (2019), "The effect of supply chain agility on export performance: The mediating roles of supply chain responsiveness and innovativeness", Journal of Manufacturing Technology Management, Vol.30, No. 5, pp. 821-839.

Bartolucci, C., Antonacci, A., Arduini, F., Moscone, D., Fraceto, L., Campos, E., ...Scognamiglio, V.(2020), "Green nanomaterials fostering agrifood sustainability", Green nanomaterials fostering agrifood sustainability, Vol.125, p. 115840.

Bitzer, V., and Bijman, J.(2015), "From innovation to co-innovation? An exploration of African agrifood chains", British Food Journal, Vol.117, No. 8, pp. 2182-2199.

Boudlaie, H., Mahdiraji, H.A., Shamsi, S., Jafari-Sadeghi, V., and Garcia-Pereze, A.(2020), "Designing a human resource scorecard: An empirical stakeholder-based study with a company culture perspective", Journal of Entrepreneurship, Management and Innovation, Vol.16, No.4, pp.113-147. 
Brun, J., Jeuffroy, M.H., Pénicaud, C., Cerf, M., and Meynard, J.M.(2021), "Designing a research agenda for coupled innovation towards sustainable agrifood systems", Agricultural Systems, Vol.191, p. 103143.

Bryceson, K.P., and Ross, A.(2020), "Agrifood chains as complex systems and the role of informality in their sustainability in small scale societies", Sustainability (Switzerland), Vol.12, No. 16, p. 6535.

Bux, H., Zhang, Z., and Ahmad, N.(2020), "Promoting sustainability through corporate social responsibility implementation in the manufacturing industry: An empirical analysis of barriers using the ISMMICMAC approach", Corporate Social Responsibility and Environmental Management, Vol.27, No.4, pp.1729-1748.

Cheraghi, S., Choobchain, S., and Abbasi, E.(2020), "Impact of institutional pressure on investment decisionmaking process in renewable energy technologies in the agricultural sector, Iran", Plant Archives, Vol.20, No.1, pp. 1743-1751.

Chesbrough, H.(2011), Open Services Innovation: Rethinking Your Business to Grow and Compete in a New Era. Presentation.

Cotes-Torres, A., Muñoz-Gallego, P.A., and Cotes-Torres, J.M.(2016), "Technological complexity: a tool for understanding the behaviour of consumers of high value-added foodstuffs", Journal of Business Economics and Management, Vol.17, No.3, pp. 444-457.

Cuer, L., Correa Bernardo, C.H., and Scalco, A.R.(2019), "Lean approach in the agrifood chain: a systematic bibliographic review", Revista De Gestao E Projetos, Vol.10, No.2, pp. 93-106.

Dahri, A.F., and Yunus, A.M.(2018), "The Effectiveness of Social Media as Knowledge Management Sharing Tool in Government Agency: A Case Study", International Journal of Academic Research in Business and Social Sciences, Vol.7, No.12, pp. 1189-1199.

Di Pietro, F., Monaghan, S., and O'Hagan-Luff, M.(2021), "Entrepreneurial Finance and HRM Practices in Small Firms", British Journal of Management.

Dorcheh, F.R., Hajiagha, S.H.R., Rahbari, M., Jafari-Sadeghi, V., and Mahdiraji, H.A.(2021), "Identification, analysis and improvement of red meat supply chain strategies considering the impact of COVID-19 pandemic: a hybrid SWOT-QSPM approach in an emerging economy", British Food Journal.

Du, Y.W., and Li, X.X.(2021), "Hierarchical DEMATEL method for complex systems", Expert Systems with Applications, Vol.167, p.113871.

Englund, T.R., Zhou, M., Hedrick, V.E., and Kraak, V.I.(2020), "How Branded Marketing and Media Campaigns Can Support a Healthy Diet and Food Well-Being for Americans: Evidence for 13 Campaigns in the United States", Journal of Nutrition Education and Behavior, Vol.52, No.1, pp. 8795.

Fagundes, M.V., Teles, E.O., Vieira de Melo, S.A., and Freires, F.G.(2020), "Decision-making models and support systems for supply chain risk: literature mapping and future research agenda", European Research on Management and Business Economics, Vol.26, No.2, pp. 63-70.

Fiankor, D.D., Flachsbarth, I., Masood, A., and Brümmer, B.(2020), "Does Global GAP certification promote agrifood exports?", European Review of Agricultural Economics, Vol.47, No.1, pp. 247-272.

Filippi, M., and Chapdaniel, A.(2021), "Sustainable demand-supply chain: An innovative approach for improving sustainability in agrifood chains", International Food and Agribusiness Management Review, Vol.24, No.2, pp. 321-335.

Finco, A., Bentivoglio, D., and Bucci, G.(2018), "Lessons of innovation in the agrifood sector: Drivers of innovativeness performances", Economia Agro-Alimentare, Vol.20, No.2, pp. 181-192.

Folinas, D., Aidonis, D., Voulgarakis, N., and Triantafylou, D.(2013), "Applying Lean Thinking Techniques in the Agrifood Supply Chain", 1st Logistics International Conference, Belgrade, Serbia, 28-30 November 2013.

Gachukia, M.K.(2016), "Value chain governance and governmentality of horticultural exporters by developing economies: A perspective of Kenya's fresh fruits and vegetable export sector", International Journal on Food System Dynamics, Vol.7, No.1, pp. 1-10.

Garg, C.P.(2021), "Modeling the e-waste mitigation strategies using Grey-theory and DEMATEL framework", Journal of Cleaner Production, Vol.281, p.124035.

Ginting, Y.M., Elfindri, Rahman, H., and Devianto, D.(2020), "Impact of knowledge management in supply chain of creative industry", International Journal of Supply Chain Management, Vol.9, No.2, pp. 906911.

Gold, S., Kunz, N., and Reiner, G.(2017), "Sustainable Global Agrifood Supply Chains: Exploring the Barriers", Journal of Industrial Ecology, Vol.21, No. 2, pp. 249-260. 
Ghosh, S., Chatterjee, N.D., and Dinda, S.(2021), "Urban ecological security assessment and forecasting using integrated DEMATEL-ANP and CA-Markov models: A case study on Kolkata Metropolitan Area, India", Sustainable Cities and Society, Vol.68, p.102773.

Halabi, S.F., and Lin, C.-F.(2017), "Assessing the relative influence and efficacy of public and private food safety regulation regimes", Food and Drug Law Journal, Vol 72, p. 262.

Hashemi, S.S., Mahdiraji, H.A., Azari, M., and Hajiagha, S.H.R.(2021), "Causal modelling of failure fears for international entrepreneurs in tourism industry: a hybrid Delphi-DEMATEL based approach", International Journal of Entrepreneurial Behavior and Research.

Heshmati, A., and Dibaji, S.M.(2019), "Science, Technology, and Innovation Status in Iran: Main Challenges", Science, Technology and Society, Vol.24, No.3, pp. 545-578.

Hysa, E., Kruja, A., Rehman, N.U., and Laurenti, R.(2020), "Circular economy innovation and environmental sustainability impact on economic growth: An integrated model for sustainable development", Sustainability (Switzerland), Vol.12, No.12, p. 4831.

Jafari-Sadeghi, V., Mahdiraji, H. A., and Dana, L. P. (2021d). "Introduction: International Entrepreneurship from Methodological Perspectives", In Empirical International Entrepreneurship (pp. 1-6). Springer, Cham.

Jafari-Sadeghi, V., Sukumar, A., Pagán-Castaño, E., and Dana, L.P. (2021c), "What drives women towards domestic vs international business venturing? An empirical analysis in emerging markets", Journal of Business Research, Vol. 134, pp. 647-660.

Jafari-Sadeghi, V., Mahdiraji, H.A., Bresciani, S., and Pellicelli, A.C.(2021a), "Context-specific microfoundations and successful SME internationalisation in emerging markets: A mixed-method analysis of managerial resources and dynamic capabilities", Journal of Business Research, Vol.134, pp.352-364.

Jafari-Sadeghi, V., Amoozad Mahdiraji, H., Dana, L.P., (2021b), Empirical International Entrepreneurship: A Handbook of Methods, Approaches, and Applications.Springer Nature.

Jafari-Sadeghi, V. (2020). "The motivational factors of business venturing: opportunity versus necessity? A gendered perspective on European countries", Journal of Business Research, Vol. 113, pp. 279-289.

Jensen, P.D., and Orfila, C.(2021), "Mapping the production-consumption gap of an urban food system: an empirical case study of food security and resilience", Food Security, Vol.13, pp. 551-570.

Kach, A., and Borzabad, A.F.(2011), "Use of RFID Technology to Overcome Inefficiencies in the Supply Chain: An Analysis of Renault's Operations in Iran", International Journal of Management, Vol.28, No.4, pp. 365-378.

Kamariotou, M., Kitsios, F., Madas, M., Manthou, V., and Vlachopoulou, M. (2017, September). Strategic Decision Making and Information Management in the Agrifood Sector. In International Conference on Information and Communication Technologies in Agriculture, Food \& Environment (pp. 97-109). Springer, Cham.

Karami, Z., and Kashef, R.(2020), "Smart transportation planning: Data, models, and algorithms", Transportation Engineering, Vol.2, p. 100013.

Karimi, H., Shetab-Boushehri, S.N., and Ghadirifaraz, B.(2019), "Sustainable approach to land development opportunities based on both origin-destination matrix and transportation system constraints, case study: Central business district of Isfahan, Iran", Sustainable Cities and Society, Vol.45, pp. 499-507.

Karimi, M., Vicente-Serrano, S.M., Reig, F., Shahedi, K., Raziei, T., and Miryaghoubzadeh, M.(2020), "Recent trends in atmospheric evaporative demand in Southwest Iran: implications for change in drought severity", Theoretical and Applied Climatology, Vol.142, pp. 945-958.

Khalilpourazari, S., Soltanzadeh, S., Weber, G.W., and Roy, S.K.(2020), "Designing an efficient blood supply chain network in crisis: neural learning, optimization and case study", Annals of Operations Research, Vol.289, pp. 123-152.

Korimbocus, M.A., Singh Towokul, T., and Nagowah, S.D.(2019), "Scrum Meeting Tool for Knowledge Capture and Sharing", 2nd International Conference on Next Generation Computing Applications 2019, NextComp 2019 - Proceedings.

Kumar, S., Raut, R.D., Nayal, K., Kraus, S., Yadav, V.S., and Narkhede, B.E.(2021), "To identify industry 4.0 and circular economy adoption barriers in the agriculture supply chain by using ISM-ANP", Journal of Cleaner Production, Vol.293, p.126023.

Liu, Y., Eckert, C., Yannou-Le Bris, G., and Petit, G.(2019), "A fuzzy decision tool to evaluate the sustainable performance of suppliers in an agrifood value chain", Computers and Industrial Engineering, Vol.127, pp. 196-212. 
MacAuley, L., and Niewolny, K.(2016), "Situating On-farm Apprenticeships within the Alternative Agrifood Movement: Labor and Social Justice Implications", Journal of Agriculture, Food Systems, and Community Development, Vol.6, No.2, pp. 195-223.

Mahdiraji, H. A., Sedigh, M., Hajiagha, S. H. R., Garza-Reyes, J. A., Jafari-Sadeghi, V., and Dana, L. P. (2021), "A novel time, cost, quality and risk tradeoff model with a knowledge-based hesitant fuzzy information: An RandD project application", Technological Forecasting and Social Change, Vol. 172, pp. 121068.

Maizza, A., Fait, M., Scorrano, P., and Iazzi, A.(2019), "How Knowledge Sharing Culture Can Become a Facilitator of the Sustainable Development in the Agrifood Sector", Sustainability (Switzerland), Vol.11, No.4, pp. 952.

Meynard, J.M., Jeuffroy, M.H., Le Bail, M., Lefèvre, A., Magrini, M.B., and Michon, C.(2017), "Designing coupled innovations for the sustainability transition of agrifood systems", Agricultural Systems, Vol.157, pp. 330-339.

Mokhtarzadeh, N.G., Mahdiraji, H.A., Jafarpanah, I., Jafari-Sadeghi, V., and Bresciani, S.(2021), "Classification of inter-organizational knowledge mechanisms and their effects on networking capability: a multi-layer decision making approach", Journal of Knowledge Management, Vol.25, No.7, pp. 1665-1688.

Mubarik, M.S., Kazmi, S.H.A., and Zaman, S.I.(2021), "Application of gray DEMATEL-ANP in greenstrategic sourcing", Technology in Society, Vol.64, p.101524.

Muhummad, S., Fathelrahman, E., and Ullah, R.U.(2016), "The significance of consumer's awareness about organic food products in the United Arab Emirates", Sustainability (Switzerland), Vol.8, pp. 833.

Mulyati, T., and Utami, S.B.(2020), "SEM Analysis in the Effect of Service Quality on Customer Satisfaction and Its Implications on Student's Loyalty Online Transportation Users in Madiun Municipality", Journal of International Conference Proceedings.

Mustafa, M.B., Nordin, M.B., and Razzaq, A.B.A.(2020), "Structural Equation Modelling Using AMOS: Confirmatory Factor Analysis for Taskload of Special Education Integration Program Teachers", Univers.J.Educ.Res, Vol.8, No.1, pp.127-133.

Nagoev, A.B., Grekova, V.A., Kovalenkova, O.G., Oleynikova, J.A., and Khadueva, Y.A.(2020), "Development of supply chain management in russian catering industry: Trends and prospects in post-crisis conditions", International Journal of Supply Chain Management, Vol.9, No.2, pp. 50-85.

Nixon, P.A., and Ramaswami, A.(2018), "Assessing Current Local Capacity for Agrifood Production to Meet Household Demand: Analyzing Select Food Commodities across 377 U.S.Metropolitan Areas", Environmental Science and Technology, Vol.52, No.18, pp. 10511-10521.

O'Donoghue, C., and Heanue, K.(2018), "The impact of formal agricultural education on farm level innovation and management practices", Journal of Technology Transfer, Vol.43, pp. 844-863.

Ortega-Dela Cruz, R.(2020), "Perceptions of higher agricultural education toward sustainable agricultural development", Higher Education, Skills and Work-based Learning, Vol.10, No.1, pp. 187-202.

Oteros-Rozas, E., Ruiz-Almeida, A., Aguado, M., González, J.A., and Rivera-Ferre, M.G.(2019), "A socialecological analysis of the global agrifood system", Proceedings of the National Academy of Sciences of the United States of America, Vol.116, 52.1, pp. 26465-26473.

Pacheco, D.A., and Urbano, B.(2019), "Managerial, executive coaching characterization in the agrifood value chain", Revista de la Facultad de Agronomia, Vol.36, No.2, pp. 162-187.

Pérez-Mesa, J.C., Piedra-Muñoz, L., Galdeano-Gómez, E., and Giagnocavo, C.(2021), "Management strategies and collaborative relationships for sustainability in the agrifood supply chain", Sustainability (Switzerland), Vol.13, No.2, pp. 749.

Petridis, N.E., Digkas, G., and Anastasakis, L.(2020), "Factors affecting innovation and imitation of ICT in the agrifood sector", Annals of Operations Research, Vol.294, pp. 501-514.

Rezaei, M., Jafari-Sadeghi, V., Cao, D., and Mahdiraji, H.A.(2021), "Key indicators of ethical challenges in digital healthcare: A combined Delphi exploration and confirmative factor analysis approach with evidence from Khorasan province in Iran", Technological Forecasting and Social Change, Vol.167, p. 120724 .

Rezaei, M., Soheilifard, F., and Keshvari, A.(2021), "Impact of agrochemical emission models on the environmental assessment of paddy rice production using life cycle assessment approach", Energy Sources, Part A: Recovery, Utilization and Environmental Effects.

Rodrigo, I., Cristóvão, A., Tibério, M.L., Baptista, A., Maggione, L., and Pires, M.(2015), "The Portuguese agrifood traditional products: Main constraints and challenges", Revista de Economia e Sociologia Rural, Vol.53, No.1, pp. 23-32. 
Ronteltap, A., Reinders, M.J., van Dijk, S.M., Heijting, S., van der Lans, I.A., and Lotz, L.A.(2016), "How Technology Features Influence Public Response to New Agrifood Technologies", Journal of Agricultural and Environmental Ethics, Vol.29, pp. 643-672.

Safari, F.(2018), "Restrictions and legal challenges for foreign investment in the media market in Iran", In Contributions to Management Science, Springer, Cham. https://doi.org/10.1007/978-3-319-71722711.

Sánchez-Borrego, F.J., Álvarez-Mateos, P., and García-Martín, J.F.(2021), "Biodiesel and other value-added products from bio-oil obtained from agrifood waste", Processes, Vol.9, No.5, pp. 797-815.

Saurabh, S., and Dey, K.(2021), Blockchain technology adoption, architecture, and sustainable agri-food supply chains. Journal of Cleaner Production, Vol.284, p. 124731

Schniederjans, D.G., Curado, C., and Khalajhedayati, M.(2020), "Supply chain digitisation trends: An integration of knowledge management", International Journal of Production Economics, Vol.220, p. 107439.

Schwendner, A.A., Lam, T.J., Bodmer, M., Cousin, M.E., Schüpbach-Regula, G., and van den Borne, B.H.(2020), "Knowledge, attitude and practices of Swiss dairy farmers towards intramammary antimicrobial use and antimicrobial resistance: A latent class analysis", Preventive Veterinary Medicine, Vol.179, p. 105023.

Shanker, S., and Barve, A.(2021), "Analysing sustainable concerns in diamond supply chain: a fuzzy ISMMICMAC and DEMATEL approach", International Journal of Sustainable Engineering, Vol.14, No.5, pp. 1269-1285.

Shkolnyi, O.O., and Novak, I.M.(2020), "Risk management in export-oriented supply chains of agrifood commodities", Collected Works of Uman National University of Horticulture.

Singh, C., Singh, D., and Khamba, J.S.(2020), "Developing a conceptual model to implement green lean practices in Indian manufacturing industries using ISM-MICMAC approach", Journal of Science and Technology Policy Management, Vol.12, No.4, pp. 587-608.

Sonar, H., Khanzode, V., and Akarte, M.(2020), "Investigating additive manufacturing implementation factors using integrated ISM-MICMAC approach", Rapid Prototyping Journal, Vol.26, No.10, pp. 1837-1851.

Trivedi, A., Jakhar, S.K., and Sinha, D.(2021), "Analyzing barriers to inland waterways as a sustainable transportation mode in India: a dematel-ISM based approach", Journal of Cleaner Production, Vol.295, p.126301.

Tsolakis, N., Aivazidou, E., and Srai, J.S.(2019), "Sensor applications in agrifood systems: Current trends and opportunities for water stewardship", Sensor applications in agrifood systems: Current trends and opportunities for water stewardship, Vol.7, No.44.

Ulvenblad, P., Barth, H., Ulvenblad, P.O., Ståhl, J., and Björklund, J.C.(2020), "Overcoming barriers in agribusiness development: two education programs for entrepreneurs in the Swedish agricultural sector", Journal of Agricultural Education and Extension, Vol.26, No.5, pp. 443-464.

van der Vorst, J.G., van Kooten, O., and Luning, P.A.(2011), "Towards a Diagnostic Instrument to Identify Improvement Opportunities for Quality Controlled Logistics in Agrifood Supply Chain Networks", International Journal on Food System Dynamics, Vol.2, No.1, pp. 1-12.

Wen, Z., Liao, H., Zavadskas, E.K., and Antuchevičienè, J. (2021), Applications of fuzzy multiple criteria decision making methods in civil engineering: a state-of-the-art survey, Journal of Civil Engineering and Management, Vol.27, No.6, pp. 358-371.

Xia, X., and Ruan, J.(2020), "Analyzing Barriers for Developing a Sustainable Circular Economy in Agriculture in China Using Grey-DEMATEL Approach", Sustainability, Vol.12, No.16, p.6358.

Yildirim, S., Röcker, B., Pettersen, M.K., Nilsen-Nygaard, J., Ayhan, Z., and Rutkaite, R.(2018), "Active packaging applications for food", Compr Rev Food Sci Food Saf, Vol 17, No.1, pp.165-199. 
Table 1. Barriers and sub-categories of Investigating in the agri-food sector for IEs

\begin{tabular}{llc}
\hline Main Barrier & Sub-categories & Code \\
\multirow{2}{*}{ Fundamental } & Assets and Infrastructure $^{1}$ & $\mathbf{B}_{\mathbf{1}}$ \\
& Technology $^{2}$ & $\mathbf{B}_{\mathbf{2}}$ \\
\hline \multirow{2}{*}{ Supply Chain } & Supply chain efficiency $^{3}$ & $\mathbf{B}_{\mathbf{3}}$ \\
& Supply chain responsiveness $^{4}$ & $\mathbf{B}_{\mathbf{4}}$ \\
\hline \multirow{3}{*}{ Sustainability } & Environmentally friendly behavior $^{5}$ & $\mathbf{B}_{\mathbf{5}}$ \\
& Social responsibility $^{6}$ & $\mathbf{B}_{\mathbf{6}}$ \\
& Economic sustainability $^{7}$ & $\mathbf{B}_{\mathbf{7}}$ \\
\hline \multirow{2}{*}{ Knowledge } & Innovation $^{8}$ & $\mathbf{B}_{\mathbf{8}}$ \\
& Knowledge management $^{9}$ & $\mathbf{B}_{\mathbf{9}}$ \\
\hline \multirow{2}{*}{ Policy } & Governmental Support and flexible regulations $^{10}$ & $\mathbf{B}_{\mathbf{1 0}}$ \\
& Regional and Global economy/Market $^{11}$ & $\mathbf{B}_{\mathbf{1 1}}$ \\
\hline
\end{tabular}

1. Assets \& Infrastructure. Limited access to several transportation modes, non-availability of multimodal and intermodal transportation systems, traditional processes in ports, borders and customs, non-developed ports, etc.

2. Technology. Traditional and classical agri-food technology, limited use of information and communication technology in the agricultural sector, limited access and use of internet amongst the farmers, non-technical and traditional farmers, etc.

3. Supply chain efficiency. The measure of getting the right product to the right place at the right time at the least cost including high production cost of agrifood in Iran, low quality in the distribution of agri-food sector, high level of waste in agri-food transportation, etc.

4. Supply chain responsiveness. The ability of the supply chain to respond purposefully and within an appropriate timeframe to customer requests or changes in the marketplace including inflexibility of the agri-food supply chain, etc.

5. Environmentally friendly behaviour. Includes non-eco-friendly activities and non-green products, using up too many resources or causing pollution, depletion of natural resources, etc.

6. Social responsibility. Unethical treatment with farmers, modern slavery in the agri-food sector, child slavery in the agri-food sector in Iran, gender slavery in the agri-food sector in Iran, forced labour, the imbalance between the economy and the ecosystems, etc.

7. Economic sustainability. Short-term economic growth negatively impacting social, environmental, and cultural aspects of the community. Low profit, revenue and benefit for the farmers in the agri-food sector, etc.

8. Innovation. Low implementation of ideas without any result in the introduction of new goods or services or improvement in offering goods or services in the agri-food sector, etc.

9. Knowledge management. Low level of knowledge in the agri-food sector, knowledge hiding, low usage of knowledge and information in the agri-food sector, etc.

10. Governmental Support and flexible regulations. Non-supportive regulations, rigid and traditional processes, barriers to enter the agri-food sector, governmental and public sector organizations in the agri-food industry of Iran, low level of competition, high level of corruption amongst the officials and authorities, etc.

11. Regional \& Global economy/Market. Limited access and membership in regional trade agreements, restricted political and economic relationships, lowlevel free trade zones, etc. 
Table 2. Experts Profile

\begin{tabular}{cccllc}
\hline Case & Gender & Age groups & Education & \multicolumn{1}{c}{ Area } & Experience (yrs) \\
\hline 1 & M & $40 \mathrm{~s}$ & PG & Industry Expert & $10+$ \\
2 & M & $30 \mathrm{~s}$ & PG & Industry Expert & $15+$ \\
3 & M & $40 \mathrm{~s}$ & DBA & Officials & $10+$ \\
4 & $\mathrm{~F}$ & $50 \mathrm{~s}$ & DBA & Officials & $15+$ \\
5 & $\mathrm{M}$ & $50 \mathrm{~s}$ & PG & Officials & $15+$ \\
6 & $\mathrm{M}$ & $40 \mathrm{~s}$ & PHD & Academician & $10+$ \\
7 & $\mathrm{M}$ & $40 \mathrm{~s}$ & PHD & Industry Expert & $15+$ \\
8 & $\mathrm{~F}$ & $30 \mathrm{~s}$ & PG & Industry Expert & $15+$ \\
9 & $\mathrm{~F}$ & $50 \mathrm{~s}$ & PHD & Academician & $15+$ \\
10 & $\mathrm{~F}$ & $30 \mathrm{~s}$ & PG & Officials & $5+$ \\
11 & $\mathrm{~F}$ & $30 \mathrm{~s}$ & PG & Industry Expert & $10+$ \\
12 & $\mathrm{M}$ & $40 \mathrm{~s}$ & PHD & Academician & $15+$ \\
13 & $\mathrm{M}$ & $50 \mathrm{~s}$ & PG & Industry Expert & $15+$ \\
14 & $\mathrm{M}$ & $30 \mathrm{~s}$ & PHD & Academician & $15+$ \\
15 & $\mathrm{M}$ & $50 \mathrm{~s}$ & PHD & Academician & $10+$ \\
\hline
\end{tabular}


Table 3. Linguistic terms transfer values

\begin{tabular}{lll}
\hline Linguistic Term & Symbol & Numerical Value \\
\hline Very very high & VVH & 9 \\
Very high & VH & 8 \\
High & H & 7 \\
Nearly High & NH & 6 \\
Neither High nor low & NHNL & 5 \\
Nearly Low & NL & 4 \\
Low & L & 3 \\
Very Low & VL & 2 \\
Very Very Low & VVL & 1 \\
\hline
\end{tabular}


Table 4. A review on applications of MCDM in the agri-food industry

\begin{tabular}{|c|c|c|c|c|c|c|}
\hline \multirow[t]{2}{*}{ Author(s) } & \multirow[t]{2}{*}{ Year } & \multirow[t]{2}{*}{ Method(s) } & \multirow[t]{2}{*}{ Purpose } & \multirow[t]{2}{*}{ Deterministic } & \multicolumn{2}{|c|}{ Uncertain } \\
\hline & & & & & Fuzzy & Grey \\
\hline $\begin{array}{l}\text { Castro Silva } \\
\text { et al. }\end{array}$ & 2015 & PROMETHEE II & $\begin{array}{l}\text { Improving fruit production } \\
\text { and distribution value chain }\end{array}$ & & $\checkmark$ & \\
\hline $\begin{array}{l}\text { De Oliveira } \\
\text { et al. }\end{array}$ & 2016 & AHP & $\begin{array}{l}\text { Determining sustainable } \\
\text { milk production system } \\
\text { hierarchy }\end{array}$ & $\checkmark$ & & \\
\hline Fagioli et al. & 2017 & ELECTRE III & $\begin{array}{l}\text { Analyzing the multi- } \\
\text { functionality of the agri-food } \\
\text { value chain }\end{array}$ & & $\checkmark$ & \\
\hline $\begin{array}{l}\text { Khishtandar, } \\
\text { et al. }\end{array}$ & 2017 & $\begin{array}{l}\text { Hesitant Fuzzy } \\
\text { Linguistic Term Set } \\
\text { (HFLTS) }\end{array}$ & $\begin{array}{l}\text { Evaluate bioenergy } \\
\text { technologies for sustainable } \\
\text { production in agriculture and } \\
\text { industry }\end{array}$ & & $\checkmark$ & \\
\hline Kaim et al. & 2018 & $\begin{array}{l}\text { multi-criteria } \\
\text { decision analysis } \\
\text { (MCDA) }\end{array}$ & $\begin{array}{l}\text { Optimizing land-use } \\
\text { allocation in agriculture }\end{array}$ & $\checkmark$ & & \\
\hline Rezaei, et al. & 2018 & $\begin{array}{l}\text { Best Worst Method } \\
\text { (BWM) }\end{array}$ & Optimal package designs & $\checkmark$ & & \\
\hline $\begin{array}{l}\text { Sen and } \\
\text { Kansal }\end{array}$ & 2019 & $\begin{array}{l}\text { multi-criteria analysis } \\
\text { (MCA) }\end{array}$ & $\begin{array}{l}\text { Sustainable development of } \\
\text { cardamom production using } \\
\text { value chain approach }\end{array}$ & $\checkmark$ & & \\
\hline Grover et al. & 2019 & $\begin{array}{c}\text { multiple-attribute } \\
\text { value theory (MAVT) }\end{array}$ & $\begin{array}{l}\text { Evaluate the grain } \\
\text { distribution scheme in } \\
\text { Indian Punjab }\end{array}$ & $\checkmark$ & & \\
\hline Sari, et al. & 2020 & $\begin{array}{c}\text { AHP and } \\
\text { PROMETHEE }\end{array}$ & Selecting apiary location & $\checkmark$ & & \\
\hline Xia and Ruan & 2020 & DEMATEL & $\begin{array}{l}\text { Identifying barriers in the } \\
\text { circular economy }\end{array}$ & & & $\checkmark$ \\
\hline Kumar et al. & 2021 & ISM-ANP & $\begin{array}{l}\text { Selecting of third-party } \\
\text { logistics services }\end{array}$ & & $\checkmark$ & \\
\hline Lizot et al. & 2021 & $\begin{array}{l}\text { Cost management } \\
\text { model }\end{array}$ & Supplier selection & $\checkmark$ & & \\
\hline
\end{tabular}


Table 5a. Initial ISM Matrix completed by IEs panel

\begin{tabular}{|c|c|c|c|c|c|c|c|c|c|c|c|c|}
\hline B & $\mathbf{B}_{1}$ & $\mathbf{B}_{2}$ & $\mathbf{B}_{3}$ & $\mathbf{B}_{4}$ & B $_{5}$ & B $_{6}$ & $\mathbf{B}_{7}$ & $\mathbf{B}_{8}$ & B9 & $\mathbf{B}_{10}$ & $\mathbf{B}_{11}$ & \\
\hline $\mathbf{B}_{1}$ & & $\mathrm{~V}$ & $\mathrm{~V}$ & $\mathrm{~V}$ & $\mathrm{O}$ & $\mathrm{V}$ & $X$ & V & $\mathrm{O}$ & A & $\mathrm{V}$ & \\
\hline $\mathbf{B}_{2}$ & & & V & V & V & $\mathrm{V}$ & $X$ & $X$ & V & V & V & \\
\hline $\mathbf{B}_{3}$ & & & & $X$ & V & V & V & A & $\mathrm{O}$ & A & $\mathrm{A}$ & \\
\hline $\mathbf{B}_{4}$ & & & & & $\mathrm{~V}$ & V & $\mathrm{V}$ & A & $\mathrm{O}$ & $\mathrm{O}$ & 0 & \\
\hline $\mathbf{B}_{5}$ & & & & & & 0 & A & A & A & A & $\mathrm{O}$ & \\
\hline $\mathbf{B}_{6}$ & & & & & & & A & A & $\mathrm{O}$ & A & 0 & \\
\hline $\mathbf{B}_{7}$ & & & & & & & & $X$ & $\mathrm{O}$ & A & V & \\
\hline $\mathbf{B}_{8}$ & & & & & & & & & $\mathrm{O}$ & $\mathrm{V}$ & $X$ & \\
\hline B9 & & & & & & & & & & $\mathrm{O}$ & $\mathrm{O}$ & \\
\hline $\mathbf{B}_{10}$ & & & & & & & & & & & $X$ & \\
\hline $\mathbf{B}_{11}$ & & & & & & & & & & & & \\
\hline \multicolumn{13}{|c|}{ Table 5b. Final Reachability Matrix (FRM) } \\
\hline FRM & $\mathbf{B}_{1}$ & $\mathbf{B}_{2}$ & $\mathbf{B}_{3}$ & $\mathbf{B}_{4}$ & $\mathbf{B}_{5}$ & $\mathbf{B}_{6}$ & $\mathbf{B}_{7}$ & $\mathbf{B}_{8}$ & $\mathbf{B}_{9}$ & $\mathbf{B}_{10}$ & $\mathbf{B}_{11}$ & $\begin{array}{l}\text { Driver } \\
\text { Power } \\
\end{array}$ \\
\hline $\mathbf{B}_{1}$ & 1 & 1 & 1 & 1 & $1^{*}$ & 1 & 1 & 1 & $1 *$ & $1^{*}$ & 1 & 11 \\
\hline $\mathbf{B}_{2}$ & $1^{*}$ & 1 & 1 & 1 & 1 & 1 & 1 & 1 & 1 & 1 & 1 & 11 \\
\hline $\mathbf{B}_{3}$ & $1^{*}$ & $1^{*}$ & 1 & 1 & 1 & 1 & 1 & $1 *$ & 0 & 0 & $1^{*}$ & 9 \\
\hline $\mathbf{B}_{4}$ & $1^{*}$ & $1^{*}$ & 1 & 1 & 1 & 1 & 1 & $1 *$ & 0 & 0 & $1^{*}$ & 9 \\
\hline $\mathbf{B}_{5}$ & 0 & 0 & 0 & 0 & 1 & 0 & 0 & 0 & 0 & 0 & 0 & 1 \\
\hline $\mathbf{B}_{6}$ & 0 & 0 & 0 & 0 & 0 & 1 & 0 & 0 & 0 & 0 & 0 & 1 \\
\hline $\mathbf{B}_{7}$ & 1 & 1 & $1^{*}$ & $1^{*}$ & 1 & 1 & 1 & 1 & $1^{*}$ & $1^{*}$ & 1 & 11 \\
\hline $\mathbf{B}_{8}$ & $1^{*}$ & 1 & 1 & 1 & 1 & 1 & 1 & 1 & $1 *$ & 1 & 1 & 11 \\
\hline $\mathbf{B}_{9}$ & 0 & 0 & 0 & 0 & 1 & 0 & 0 & 0 & 1 & 0 & 0 & 2 \\
\hline $\mathbf{B}_{10}$ & 1 & $1^{*}$ & 1 & $1^{*}$ & 1 & 1 & 1 & $1 *$ & 0 & 1 & 1 & 10 \\
\hline \multirow{2}{*}{$\begin{array}{c}\mathbf{B}_{11} \\
\text { Dependence } \\
\text { Power }\end{array}$} & $1^{*}$ & $1^{*}$ & 1 & $1 *$ & $1^{*}$ & $1 *$ & $1^{*}$ & 1 & 0 & 1 & 1 & 10 \\
\hline & 8 & 8 & 8 & 8 & 10 & 9 & 8 & 8 & 5 & 6 & 8 & 86 \\
\hline
\end{tabular}


Table 6. The leveling of 11 barriers for IEs to invest in the agri-food sector of Iran

\begin{tabular}{ccccc}
\hline $\mathrm{i} / \mathrm{j}$ & Reachability set & Antecedent set & intersection set & Level \\
\hline $\mathrm{B}_{1}$ & All & All & all & 3 \\
$\mathrm{~B}_{2}$ & All & All & all & 3 \\
$\mathrm{~B}_{3}$ & $1,2,3,4,7,8,11$ & $1,2,3,4,7,8,10,11$ & $1,2,3,4,7,8,11$ & 2 \\
$\mathrm{~B}_{4}$ & $1,2,3,4,7,8,11$ & $1,2,3,4,7,8,10,11$ & $1,2,3,4,7,8,11$ & 2 \\
$\mathrm{~B}_{5}$ & 5 & $1,2,3,4,5,7,8,9,10,11$ & 5 & 1 \\
$\mathrm{~B}_{6}$ & 6 & $1,2,3,4,6,7,8,10,11$ & 6 & 1 \\
$\mathrm{~B}_{7}$ & All & All & all & 3 \\
$\mathrm{~B}_{8}$ & All & All & all & 3 \\
$\mathrm{~B}_{9}$ & 9 & $1,2,7,8,9$ & 9 & 2 \\
$\mathrm{~B}_{10}$ & All & All & all & 3 \\
$\mathrm{~B}_{11}$ & All & All & all & 3 \\
\hline
\end{tabular}


Table 7. Total Relationship Matrix of the barriers for IEs to enter the Agri-food sector

\begin{tabular}{cccccccccccc}
$\mathrm{T}$ & $\mathrm{B}_{1}$ & $\mathrm{~B}_{2}$ & $\mathrm{~B}_{3}$ & $\mathrm{~B}_{4}$ & $\mathrm{~B}_{5}$ & $\mathrm{~B}_{6}$ & $\mathrm{~B}_{7}$ & $\mathrm{~B}_{8}$ & $\mathrm{~B}_{9}$ & $\mathrm{~B}_{10}$ & $\mathrm{~B}_{11}$ \\
$\mathrm{~B}_{1}$ & 0.201 & 0.225 & 0.262 & 0.287 & 0.306 & 0.270 & 0.288 & 0.200 & 0.201 & 0.280 & 0.306 \\
$\mathrm{~B}_{2}$ & 0.409 & 0.300 & 0.437 & 0.428 & 0.437 & 0.375 & 0.433 & 0.392 & 0.393 & 0.366 & 0.457 \\
$\mathrm{~B}_{3}$ & 0.231 & 0.256 & 0.226 & 0.295 & 0.300 & 0.242 & 0.297 & 0.264 & 0.265 & 0.222 & 0.325 \\
$\mathrm{~B}_{4}$ & 0.264 & 0.256 & 0.336 & 0.231 & 0.305 & 0.253 & 0.340 & 0.244 & 0.275 & 0.255 & 0.340 \\
$\mathrm{~B}_{5}$ & 0.333 & 0.341 & 0.365 & 0.357 & 0.298 & 0.360 & 0.390 & 0.347 & 0.337 & 0.351 & 0.401 \\
$\mathrm{~B}_{6}$ & 0.271 & 0.261 & 0.288 & 0.283 & 0.279 & 0.195 & 0.282 & 0.237 & 0.238 & 0.262 & 0.291 \\
$\mathrm{~B}_{7}$ & 0.403 & 0.390 & 0.419 & 0.400 & 0.431 & 0.359 & 0.338 & 0.376 & 0.376 & 0.390 & 0.438 \\
$\mathrm{~B}_{8}$ & 0.361 & 0.359 & 0.374 & 0.367 & 0.365 & 0.327 & 0.379 & 0.258 & 0.346 & 0.339 & 0.391 \\
$\mathrm{~B}_{9}$ & 0.271 & 0.294 & 0.345 & 0.316 & 0.312 & 0.280 & 0.338 & 0.322 & 0.226 & 0.281 & 0.348 \\
$\mathrm{~B}_{10}$ & 0.365 & 0.322 & 0.366 & 0.359 & 0.389 & 0.343 & 0.372 & 0.317 & 0.307 & 0.257 & 0.383 \\
$\mathrm{~B}_{11}$ & 0.343 & 0.300 & 0.331 & 0.325 & 0.334 & 0.290 & 0.357 & 0.296 & 0.296 & 0.302 & 0.281 \\
\hline
\end{tabular}


Table 8. DEMATEL measures for the barriers

\begin{tabular}{lllll}
\hline Barrier & Direct Impact (R) & Indirect Impact (D) & Value of Barrier (D+R) & Cause/effect (R-D) \\
\hline $\mathrm{B}_{1}$ & 2.827 & 3.45 & 6.278 & -0.624 \\
$\mathrm{~B}_{2}$ & 4.427 & 3.3 & 7.731 & $\mathbf{1 . 1 2 4}$ \\
$\mathrm{B}_{3}$ & 2.923 & 3.75 & 6.672 & -0.827 \\
$\mathrm{~B}_{4}$ & 3.100 & 3.65 & 6.747 & -0.548 \\
$\mathrm{~B}_{5}$ & 3.880 & 3.76 & 7.637 & $\mathbf{0 . 1 2 3}$ \\
$\mathrm{B}_{6}$ & 2.886 & 3.29 & 6.179 & -0.407 \\
$\mathrm{~B}_{7}$ & 4.320 & 3.81 & 8.134 & 0.505 \\
$\mathrm{~B}_{8}$ & 3.866 & 3.25 & 3.866 & 3.866 \\
$\mathrm{~B}_{9}$ & 3.333 & 3.26 & 3.333 & 3.333 \\
$\mathrm{~B}_{10}$ & 3.779 & 3.3 & 7.083 & 0.476 \\
$\mathrm{~B}_{11}$ & 3.456 & 3.96 & 7.418 & -0.507 \\
\hline
\end{tabular}


Table 9. The importance of each barrier according to the DANP method

\begin{tabular}{cccccccccccccc} 
ANP & $\mathrm{B}_{1}$ & $\mathrm{~B}_{2}$ & $\mathrm{~B}_{3}$ & $\mathrm{~B}_{4}$ & $\mathrm{~B}_{5}$ & $\mathrm{~B}_{6}$ & $\mathrm{~B}_{7}$ & $\mathrm{~B}_{8}$ & $\mathrm{~B}_{9}$ & $\mathrm{~B}_{10}$ & $\mathrm{~B}_{11}$ & Average & Percent \\
$\mathrm{B}_{1}$ & 0.088 & 0.088 & 0.088 & 0.088 & 0.088 & 0.088 & 0.088 & 0.088 & 0.088 & 0.088 & 0.088 & 0.088 & $9 \%$ \\
$\mathrm{~B}_{2}$ & 0.085 & 0.085 & 0.085 & 0.085 & 0.085 & 0.085 & 0.085 & 0.085 & 0.085 & 0.085 & 0.085 & 0.085 & $9 \%$ \\
$\mathrm{~B}_{3}$ & 0.096 & 0.096 & 0.096 & 0.096 & 0.096 & 0.096 & 0.096 & 0.096 & 0.096 & 0.096 & 0.096 & 0.096 & $10 \%$ \\
$\mathrm{~B}_{4}$ & 0.094 & 0.094 & 0.094 & 0.094 & 0.094 & 0.094 & 0.094 & 0.094 & 0.094 & 0.094 & 0.094 & 0.094 & $9 \%$ \\
$\mathrm{~B}_{5}$ & 0.097 & 0.097 & 0.097 & 0.097 & 0.097 & 0.097 & 0.097 & 0.097 & 0.097 & 0.097 & 0.097 & 0.097 & $10 \%$ \\
$\mathrm{~B}_{6}$ & 0.085 & 0.085 & 0.085 & 0.085 & 0.085 & 0.085 & 0.085 & 0.085 & 0.085 & 0.085 & 0.085 & 0.085 & $8 \%$ \\
$\mathrm{~B}_{7}$ & 0.099 & 0.099 & 0.099 & 0.099 & 0.099 & 0.099 & 0.099 & 0.099 & 0.099 & 0.099 & 0.099 & 0.099 & $10 \%$ \\
$\mathrm{~B}_{8}$ & 0.084 & 0.084 & 0.084 & 0.084 & 0.084 & 0.084 & 0.084 & 0.084 & 0.084 & 0.084 & 0.084 & 0.084 & $8 \%$ \\
$\mathrm{~B}_{9}$ & 0.084 & 0.084 & 0.084 & 0.084 & 0.084 & 0.084 & 0.084 & 0.084 & 0.084 & 0.084 & 0.084 & 0.084 & $8 \%$ \\
$\mathrm{~B}_{10}$ & 0.085 & 0.085 & 0.085 & 0.085 & 0.085 & 0.085 & 0.085 & 0.085 & 0.085 & 0.085 & 0.085 & 0.085 & $9 \%$ \\
$\mathrm{~B}_{11}$ & 0.102 & 0.102 & 0.102 & 0.102 & 0.102 & 0.102 & 0.102 & 0.102 & 0.102 & 0.102 & 0.102 & 0.102 & $10 \%$ \\
\hline
\end{tabular}




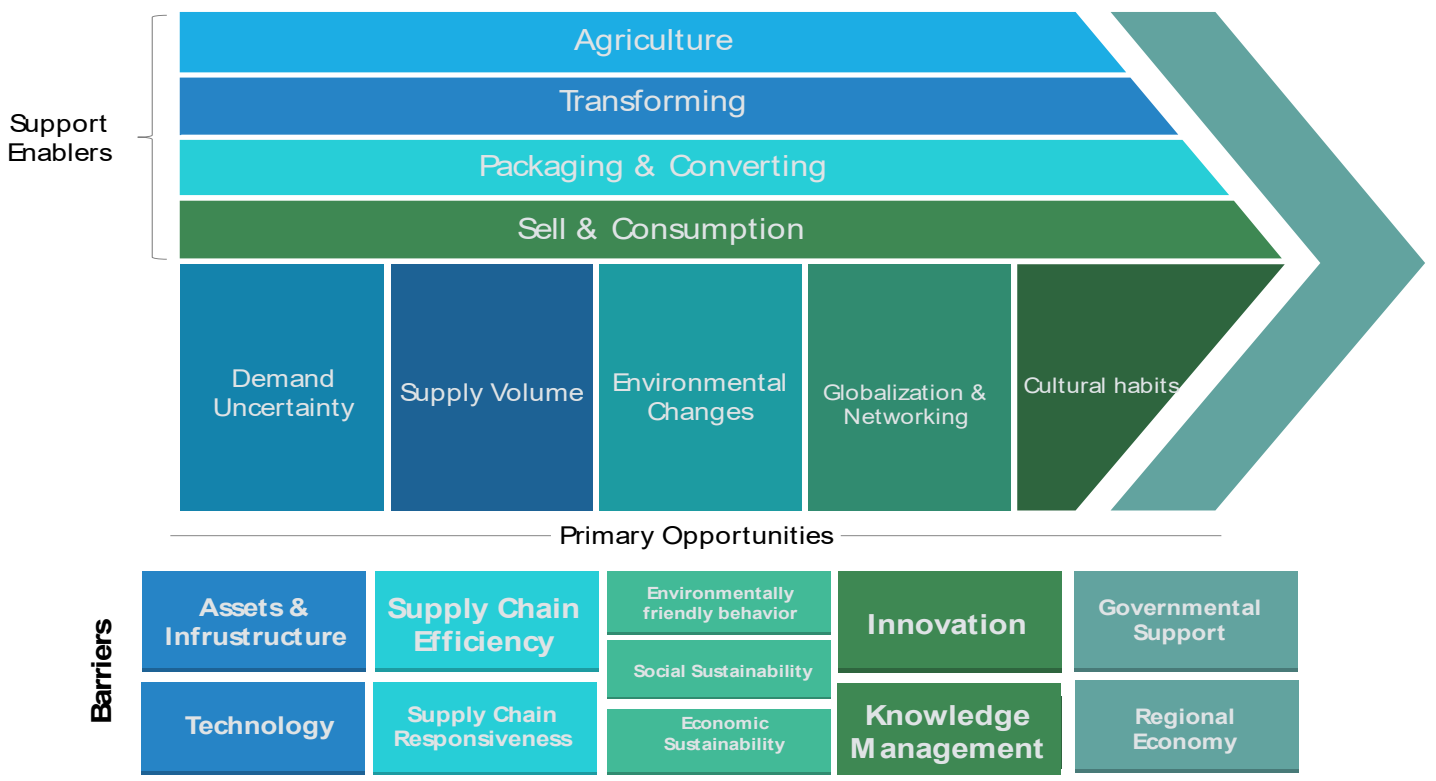

Figure 1. Value chain general framework for the agrifood sector 


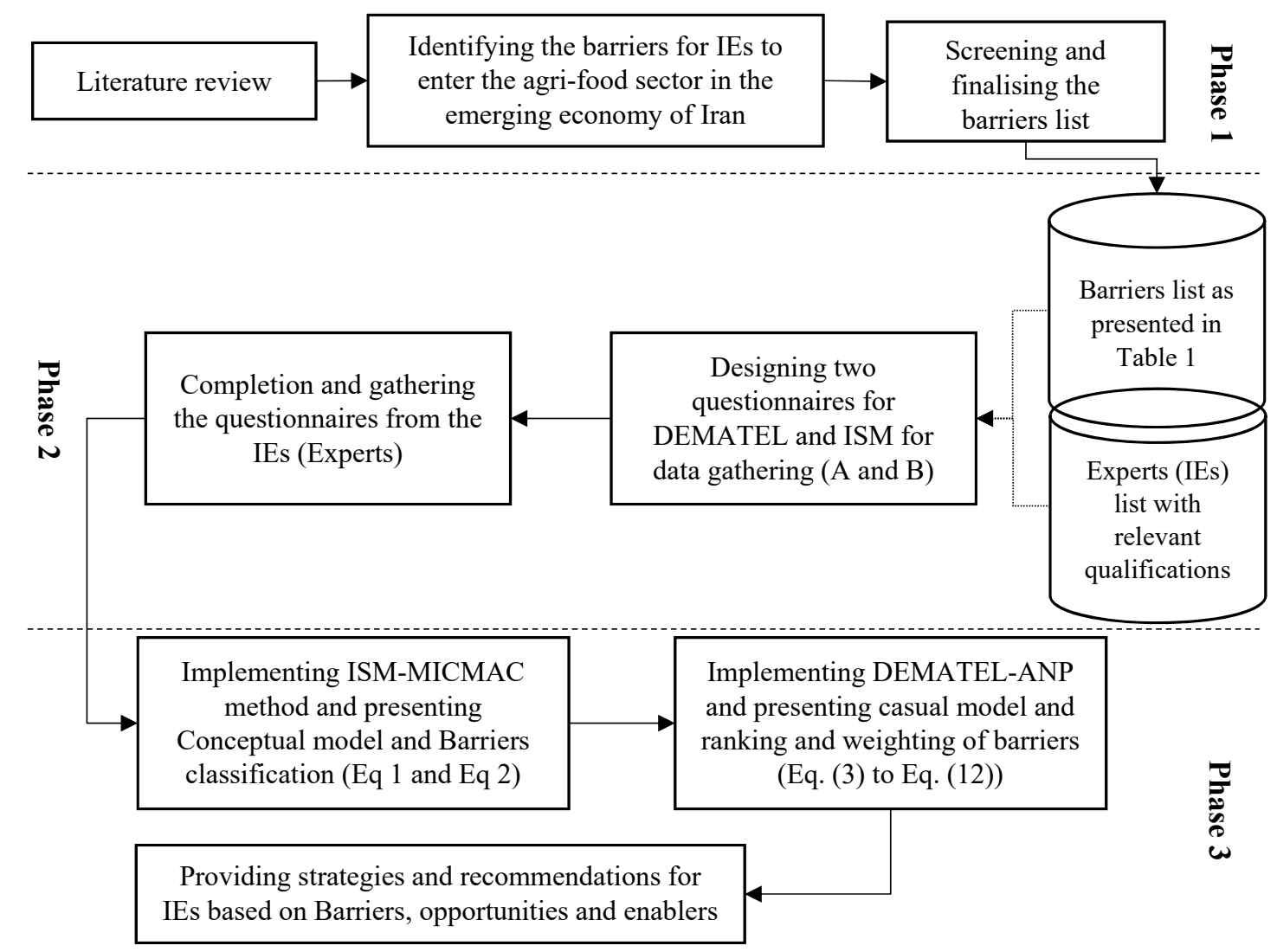

Figure 2. Research Framework 


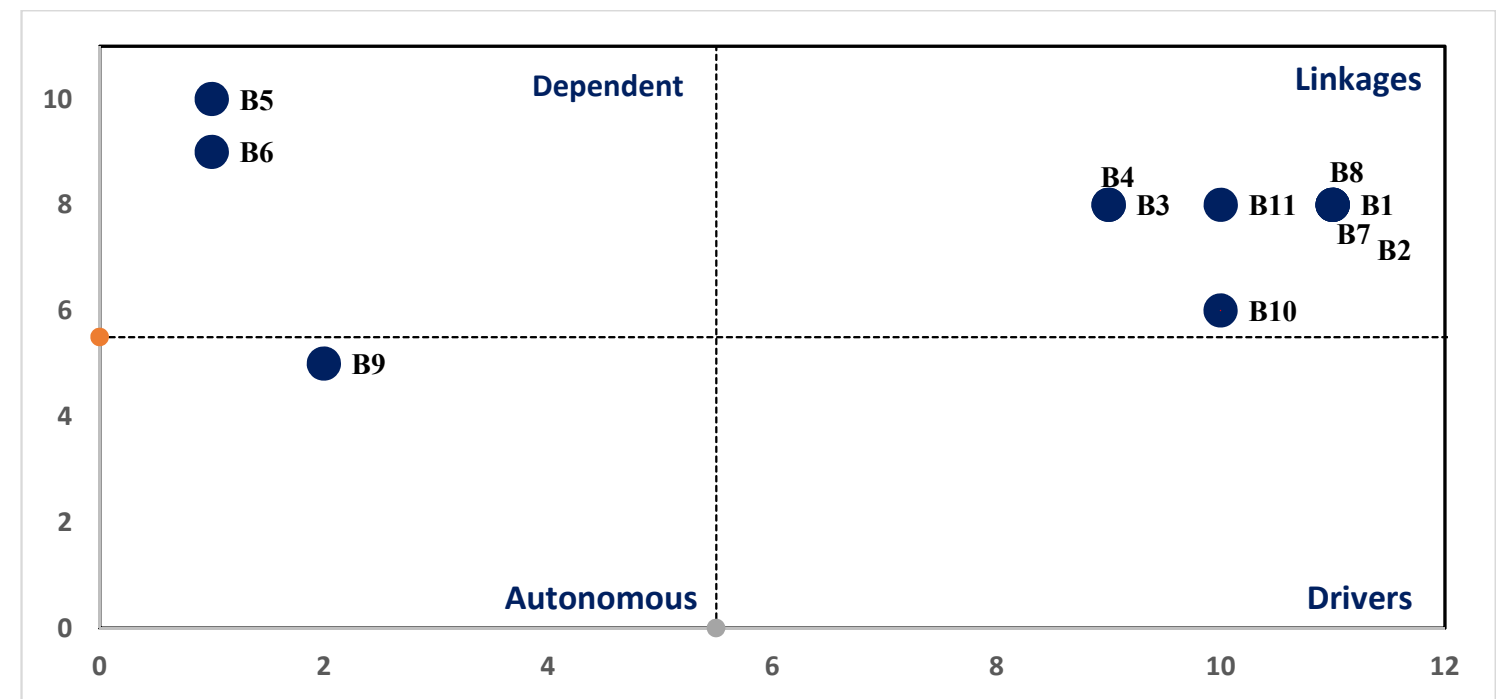

Figure 3. The DDPM result of MICMAC 


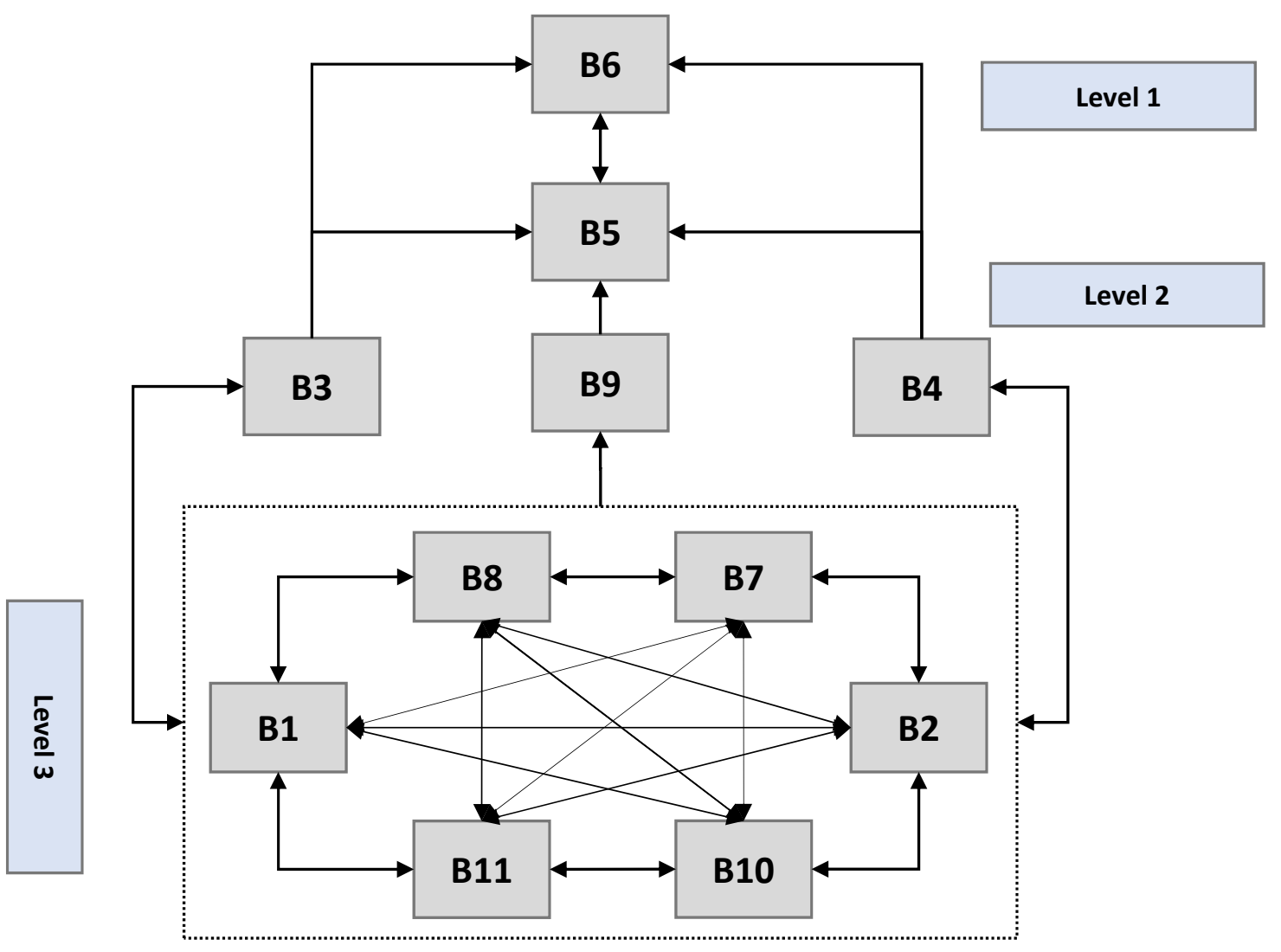

Figure 4. The level-based conceptual model for the barriers of Agri-food sector for Ies 


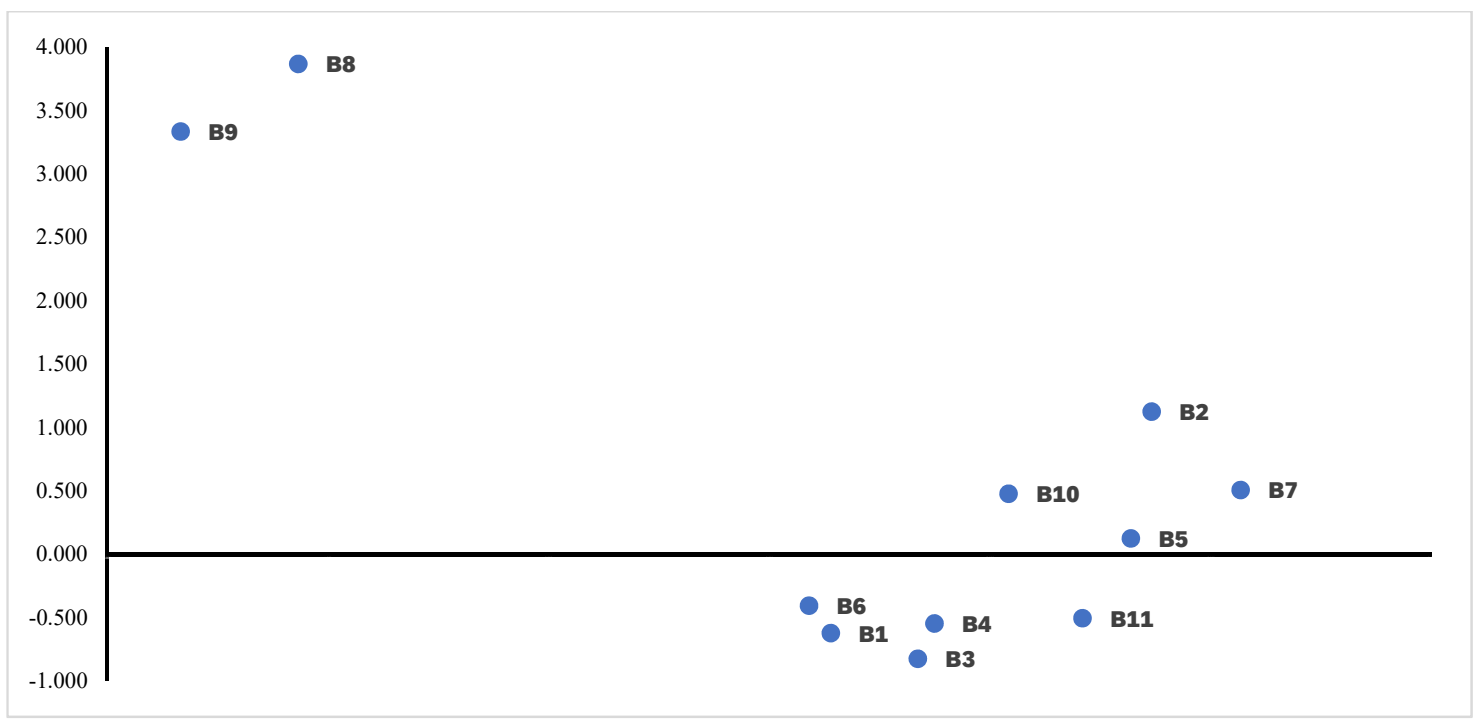

Figure 5a. Network Relationship map

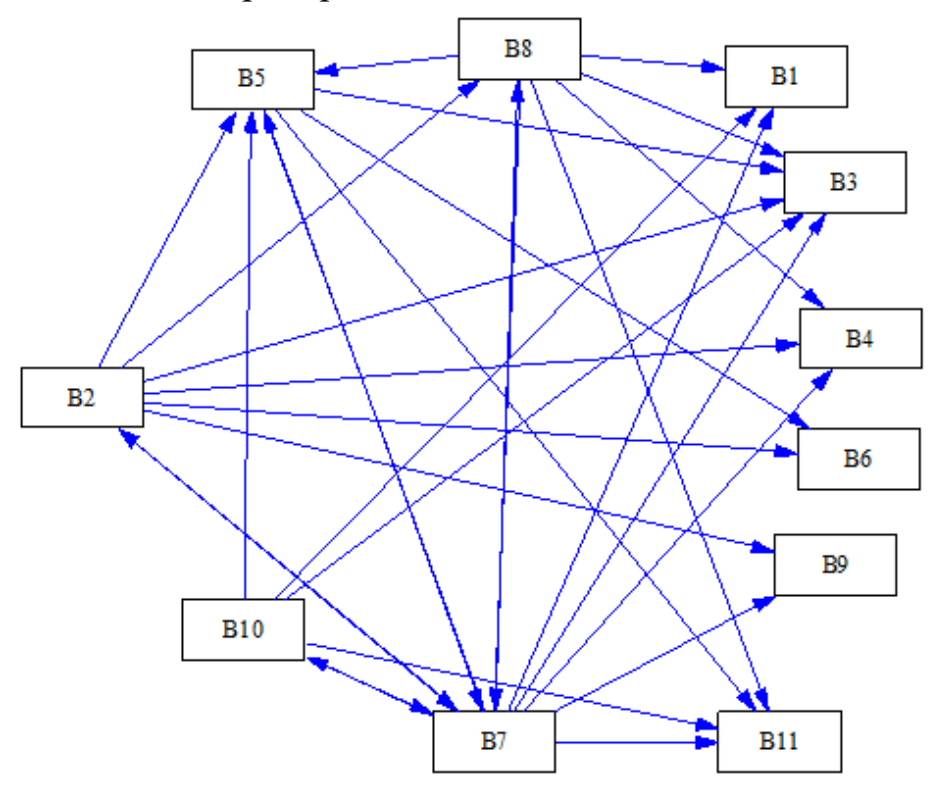

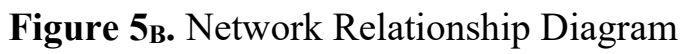




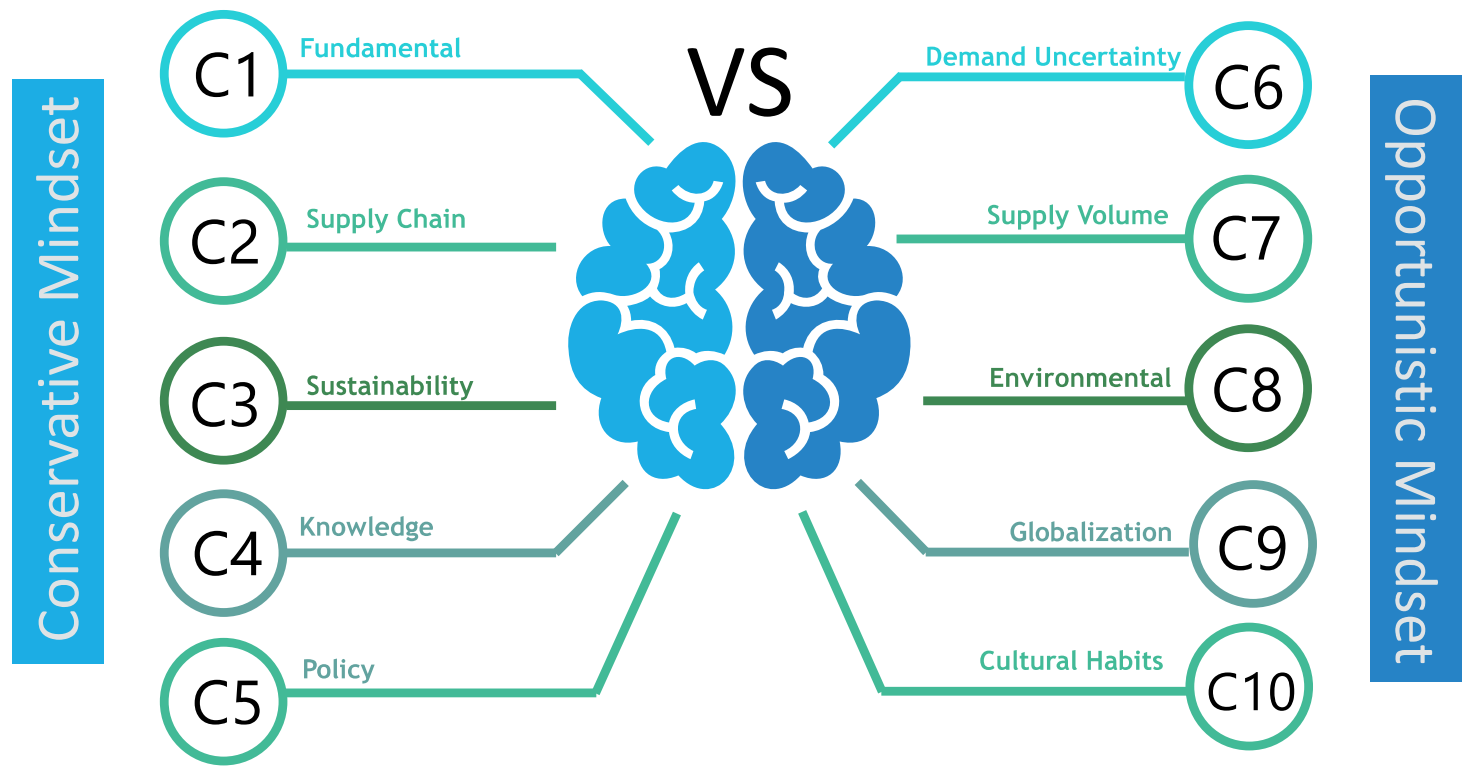

